\title{
Catalogue of the Incini with the description of the first Archedinus species from Honduras (Coleoptera: Scarabaeidae: Cetoniinae)
}

\author{
Matthias SEIDEL ${ }^{1,2,4)}$, Emmanuel ARRIAGA-VARELA ${ }^{1,2)} \&$ Rafael SOUSA $^{3)}$ \\ 1) Department of Zoology, Faculty of Science, Charles University, Prague, Viničná 7, CZ-12843, Prague, Czech Republic; \\ e-mails: matth.seidel@gmail.com, arriagavarelae@natur.cuni.cz \\ 2) Department of Entomology, National Museum, Cirkusová 1740, CZ-19300 Prague, Czech Republic; \\ ${ }^{3)}$ Museu de Zoologia da Universidade de São Paulo, Avenida Nazaré 481, Ipiranga, 04263-000, São Paulo, São Paulo, Brazil; \\ e-mail: rafael.souza1988@gmail.com \\ ${ }^{4)}$ Corresponding author
}

Accepted:
$1^{\text {st }}$ August 2018
Published online:
$10^{\text {th }}$ September 2018

Accepted:

Published online:

\begin{abstract}
We present an annotated catalogue for the tribe Incini (Coleoptera: Scarabaeidae: Cetoniinae) including references to all taxonomic and nomenclatural acts, clarifying the spelling of names, providing type depositories and occurrence records for the species. The spelling of Golinca davisii (Waterhouse, 1877) is fixed, and the incorrect subsequent spelling Pantodinus klugi Burmeister, 1847 is preserved. A comprehensive list of all valid names in Incini is provided. Furthermore, we describe the third species in the genus Archedinus Morón \& Krikken, 1990, and first one known from outside of Mexico, A. antoshkai Seidel \& Arriaga-Varela sp. nov. from Cerro las Minas, the highest mountain in Honduras. We provide an updated determination key for the species of Archedinus. The new species is compared with Archedinus howdeni Morón \& Vaz-de-Mello, 2007, the most similar species in terms of genital and habitus morphology. An updated key to identification of males of Archedinus is provided.

Key words. Coleoptera, Scarabaeidae, Cetoniinae, Coelocratus, Inca, Golinca, Pantodinus, flower chafer, faunistics, gender, nomenclature, spelling, types, taxonomy, year of description, Neotropical Region
\end{abstract}

\section{Introduction}

Incini is a Neotropical tribe of flower chafers (Coleoptera: Scarabaeidae: Cetoniinae). Previously, this group of beetles has been treated as a subtribe Incaina in the subfamily Trichiinae (e.g., Morón \& KRIKKEN 1990; MoRÓN \& VAZ-DE-Mello 2007; Sмith 2006). Smith et al. (2006) indicated the need for elevation of the subtribe to tribal level, since the historical concept of the tribe Trichiini was paraphyletic based on their preliminary molecular data. Agreeing with that, more recent works treat this group as a tribe in the subfamily Cetoniinae based on morphological and molecular phylogenetic analyses (e.g., Micó et al. 2008, ŚíPEK et al. 2016). BouchArd et al. (2011) corrected the stem and spelling of the family group name to Inc- and Incini.
The taxonomic history of the species and genera in the tribe is complex. The spelling of species names, authors and year of publication of species have been cited differently by cataloguers, taxonomists, and ecologists. The lack of a complete and comprehensive work dealing with the nomenclature in this tribe is an obstacle for taxonomists aiming to continue research on Incini.

Five Incini genera have been reported from Mexico to Argentina (Fig. 6): Archedinus Morón \& Krikken, 1990 (Figs 1-3, 5A-B), Coelocratus Burmeister, 1842 (Figs 5C-D), Inca LePeletier \& Serville, 1828 (Figs 5E-G), Golinca Thomson, 1878 (Figs 5H-J) and Pantodinus Burmeister, 1847 (Figs 5K-M).

The genus Archedinus was described by Morón \& KRIKKEN (1990) in order to include a single species, $A$. relictus 
Morón \& Krikken, 1990 from Chiapas, Mexico. Archedinus is currently classified within the tribe Incini, close to Pantodinus as a "relictual" representative with reduced sexual dimosphism. Males and females of $A$. relictus were described based on nine specimens collected in the cloud forest of El Triunfo in the Sierra Madre de Chiapas mountain range. Later, MoRón \& VAZ-DE-MeLlo (2007) described a second species, $A$. howdeni from Chimalapas region in Oaxaca, Mexico based on four male specimens and expanded the generic definition of Archedinus. The position of Archedinus within the other Incini was tested based on a morphological phylogenetic analysis, where it was sister taxon of Pantodinus and, along this one, sister to the remaining Incini. Not much is known about the life history of the genus. Archedinus relictus was reported having "diurnal activity, living under forest litter and rotten logs in montane humid forests located at elevations going from 1000 to 1850 m" (MORÓN \& KRIKKEN 1990). Archedinus howdeni was found in "tropical subdeciduous forest at 1600 m” (Morón \& VAZ-DE-Mello 2007). Besides these two type localities in Mexico, no other faunistic records have been published. Therefore, the distribution range of Archedinus is very poorly known.

In the present contribution we describe a third species recently collected in Honduras, showing that the genus is not solely endemic to Mexico and has a much larger distribution range than previously known. We update the generic diagnosis and the determination key based on the work of MORÓn \& VAZ-DE-MELlo (2007).

In addition, we present an annotated catalogue of the Incini aiming to resolve all the nomenclatural problems in the tribe.

\section{Material and methods}

Collections. The material cited is deposited in the following collections:

ADPC Alain Drumont Personal Collection, Brussels, Belgium;

AKPC Anton Kozlov Personal Collection, Moscow, Russia;

ARPC Andreas Reichenbach Personal Collection, Leipzig, Germany;

BCRC Brett Ratcliffe Personal Collection, Lincoln, Nebraska, USA;

BMNH Natural History Museum, London, United Kingdom (Max Barclay, Michael Geiser);

CEMT Setor de Entomologia da Coleção Zoológica, Universidade Federal do Mato Grosso, Cuiabá, Brazil (Fernando Vaz-deMello);

CMNC Canadian Museum of Nature Collection, Ottawa, Canada (Robert Anderson, François Génier);

DBPC Denis Bouchard Personal Collection, Autouillet, France;

DZUP Coleção Entomológica Padre Jesus Santiago Moure, Universidade Federal do Paraná, Curitiba, Brazil (Lúcia Massutti de Almeida);

EAPZ Escuela Agrícola Panamericana, Tegucigalpa, Honduras (Ron Cave, Jesús Orozco);

FZBRS Fundação Zoobotânica do Rio Grande do Sul, Porto Alegre, Brazil (Luciano de Azevedo Moura);

IEXA Colección Entomológica, Instituto de Ecología, A.C., Xalapa, México (Leonardo Delgado);

KSPC Kaoru Sakai Personal Collection, Tokyo, Japan;

LGPC Leccinum García Personal Collection, Ciudad Victoria, Tamaulipas, Mexico;

MACN Museo Argentino de Ciencias Naturales "Bernardino Rivadavia", Buenos Aires, Argentina (Arturo Roig Alsina);

MLUH Zentralmagazin Naturwissenschaftlicher Sammlungen, Martin-
-Luther-Universität Halle-Wittenberg, Halle, Germany (Karla Schneider, Joachim Händel);

MNCN Museo Nacional de Ciencias Naturales, Madrid, Spain (Mercedes París);

MNCR Museo Nacional de Costa Rica, San José, Costa Rica (Ángel Solís);

MNHN Muséum national d'Histoire naturelle, Paris, France (Antoine Mantilleri, Olivier Montreuil);

MNHG Museé d'Histoire Naturelle, Geneva, Switzerland (Giulio Cuccodoro);

MNHY Museum of Natural History, Yokohama, Japan (Kyohei Watanabe);

MSPC Matthias Seidel Personal Collection, Prague, Czech Republic;

MXAL Miguel Angel Morón Personal Collection, Xalapa, Mexico;

MZSP Museu de Zoologia da Universidade de São Paulo, São Paulo, Brazil (Sonia A. Casari);

MZUEFS Museu de Zoologia da Universidade Estadual de Feira de Santana, Feira de Santana, Brazil (Freddy Bravo);

NHRS Naturhistoriska riksmuseet, Stockholm, Sweden (Johannes Bergsten);

NMPC Department of Entomology, National Museum, Prague, Czech Republic (Lukáš Sekerka, Jiři Hájek);

PSPC Petr Šípek Personal Collection, Prague, Czech Republic;

RBINS Royal Belgian Institute of Natural Sciences, Brussels, Belgium (Alain Drumont, Pol Limbourg);

RMNH Naturalis Biodiversity Centre, Leiden, Netherlands;

SLCC Stephane LeTirant Collection, Montreal, Canada;

SMF Forschungsinstitut und Naturmuseum Senckenberg, Frankfurt am Main, Germany (Damir Kovac);

TMPC Tetsuo Mizunuma Personal Collection, Osaka, Japan;

UFRPE Coleção Entomológica, Universidade Rural de Pernambuco, Recife, Brazil (Paschoal Grossi);

UNSM University of Nebraska State Museum, Lincoln, Nebraska, USA (Brett Ratcliffe, M. J. Paulsen);

USNM United States National Museum, Washington, District of Columbia, USA (currently housed at the University of Nebraska State Museum for off-site enhancement) (Brett Ratcliffe);

UUZM Evolutionsmuseet, Uppsala University, Uppsala, Sweden (Hans Mejlon);

ZMHB Museum für Naturkunde Leibniz-Institut für Evolutions- und Biodiversitätsforschung, Berlin, Germany (Johannes Frisch, Joachim Willers);

ZMUH Zoologisches Museum, Centrum für Naturkunde, Hamburg, Germany (Martin Husemann).

Measurements. Total body length and width were measured using an electronic caliper, and measurements of other structures were obtained by using an ocular micrometer attached to an Olympus (SZX 16) dissecting microscope.

Illustrations. Habitus photographs of the new species were taken using a Canon EOS 550D digital camera with a Canon MP-E65mm f/2.8 1-5× macro lens. Photographs of all other species were provided by curators of different institutions (see Acknowledgements). Line drawings were made by hand. All morphological illustrations were subsequently edited in Adobe Photoshop CS5. Pictures of the habitat in the type locality of $A$. antoshkai were provided by Viktor Sinyaev.

Annotated catalogue. The style for the entries for species in the catalog follows Moore et al. (2017) and provide: 1) the valid species name, author and date, 2) original spelling and combination, misspellings, new combinations, and invalid names, 3) synonyms and the reference in which the synonym was designated, 4) general distribution data including the country (in capital letters) and states/provinces/departments when they are known. Distributions are based on the literature and on specimens that we examined. 


\section{Results}

\section{Archedinus Morón \& Krikken, 1990}

Type species. Archedinus relictus Morón \& Krikken, 1990: 76.

Diagnosis. This genus is distinguished from other members of the tribe Incini by the following combination of characters: body length $17-27 \mathrm{~mm}$, dorsal integument shiny, dark-brown to black; clypeal anterior margin sinuated, male with short clypeal horn or elevated clypeal margin lacking lateral or medial clypeal horns (present in Golinca, Inca and Pantodinus); eyes with strong supraocular ridges; male with antennal club longer than pedicel and funicle together, mentum with anterior margin sinuate or rounded; pronotum coarsely punctate, without posterior impression; anterior prosternal process projected, longer than procoxal length, elytra deeply striate without waxy surface; pterothoracic setae sparse; profemur with a preapical projection; protibia with 3 external teeth; meso- and metatibiae expanded, tridentate; aedeagus with parameres simple or bifurcate.

Archedinus is most similar to Pantodinus due to the sinuate antero-ventral clypeal margin and the well marked elytral striae. However, Archedinus can be distiguished by the strong supraocular ridges, the prosternal process being longer than the procoxal anterior face, and by the sparse setae on the pterosterna (Morón \& VAZ DE MELlo 2007).

The third stage larva of $A$. relictus was diagnosed from other Incini (MoRóN 1995) by having mandibles without a stridulatory area; premolar area on left mandible with 2 teeth; dorsoepicranial setae absent; maxillary stridulatory area with 12 irregular, non-pointed teeth; last antennomere with 7-13 dorsal sensory spots; tarsal claws with 2 internal preapical setae; spiracle respiratory plates with irregular, ameboid "holes"; dorsal and ventral abdominal sclerites with long setae.

\section{Archedinus antoshkai Seidel \& Arriaga-Varela, sp. nov. \\ (Figs 1A; 2A,C,E; 3A-B,D,F)}

Type material. Holotype: (NMPC), label data: "HONDURAS: Lempira / Department, P.N. Celaque Cerro / Las Minas / 14 $32^{\prime} 50^{\prime \prime} \mathrm{N}$, 8840'11' W / 01-04.vii.2014, 2600m / V. Sinyaev \& M. Márquez lgt. // ex. Matthias Seidel / Collection // Archedinus n. sp. / det. M. Seidel 2016 // HOLOTYPE / Archedinus antoshkai / sp. nov. / M. Seidel \& E. Arriaga-Varela / des. 2017'".

Description. Male (holotype). Total length: $17.5 \mathrm{~mm}$, humeral width: $7.5 \mathrm{~mm}$, maximum width: $8.5 \mathrm{~mm}$ (Figs 1A-B). Color. Ventrally and dorsally shiny black, surface in punctures dull. Head. Surface coarsely and irregularly
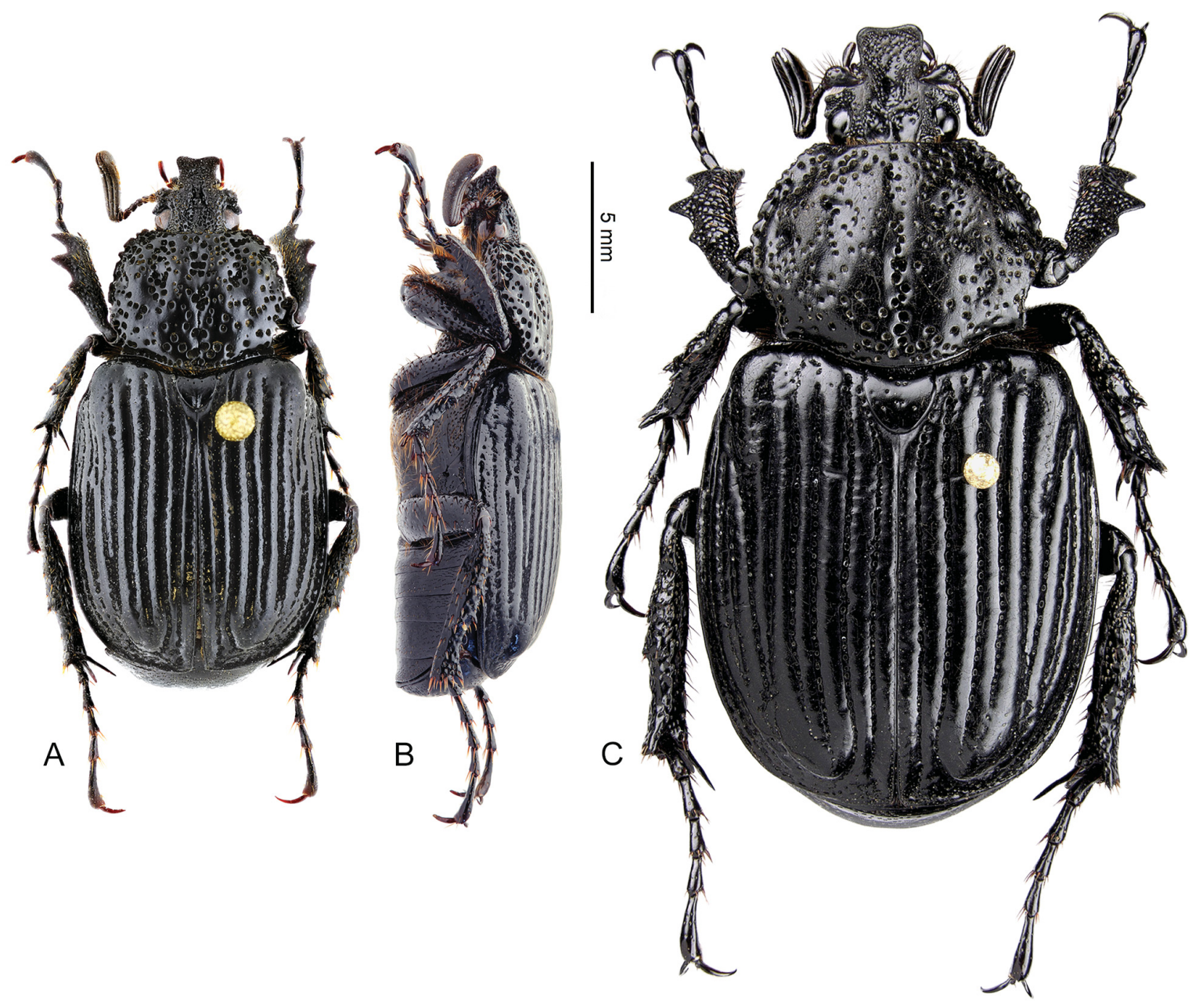

Fig. 1. Habitus views of Archedinus spp. A-B - A. antoshkai sp. nov., C - A. howdeni Morón \& Vaz-de-Mello, 2007. A, C - dorsal habitus. B - lateral habitus. Image $1 \mathrm{C}$ by courtesy of François Génier. 
punctate (Fig. 2A), with punctures ranging in diameter from 27.5-87.5 $\mu \mathrm{m}$. With a deep, long, triangular excavation, of irregular triangular shape narrowing down from frons to clypeus to a third of its width. Clypeus covered by short, tawny setae, abruptly constricted at base to 0.7 times of apical width, anterior clypeal margins sinuate with anterolateral corners reflexed. Maximum width of head capsule $3.1 \mathrm{~mm}$; maximum width of clypeus 1.5 $\mathrm{mm}$. Interocular distance equals 3.1 maximum transverse eye diameters.

Labium elongate, narrowing anteriorly with anterior margin slightly rounded (Fig. 3D), deeply punctate, seti- gerous; setae long, tawny. Distal maxillary palpomere 0.8 $\mathrm{mm}$ in length, subcylindrical, weakly curved, apex truncate. Third palpomere subfusiform, rounded, not connate with second, enlarged, $0.6 \mathrm{~mm}$ long. Antennae with 10 antennomeres, antennal club composed of three enlarged, lamellate antennomeres, club $2.6 \mathrm{~mm}$ long, 1.7 times longer than preceding six antennomeres combined; antennomere 7 wider than long, with narrowed, short anterior projection; antennomere 6 longer than wide, with apex obliquely truncate, without anterior projection; antennomere 3 as long as antennomere 4 or 5 , antennomere 3 as long as wide, pedicel nearly globular, as wide as long; scape elongate-pyriform.
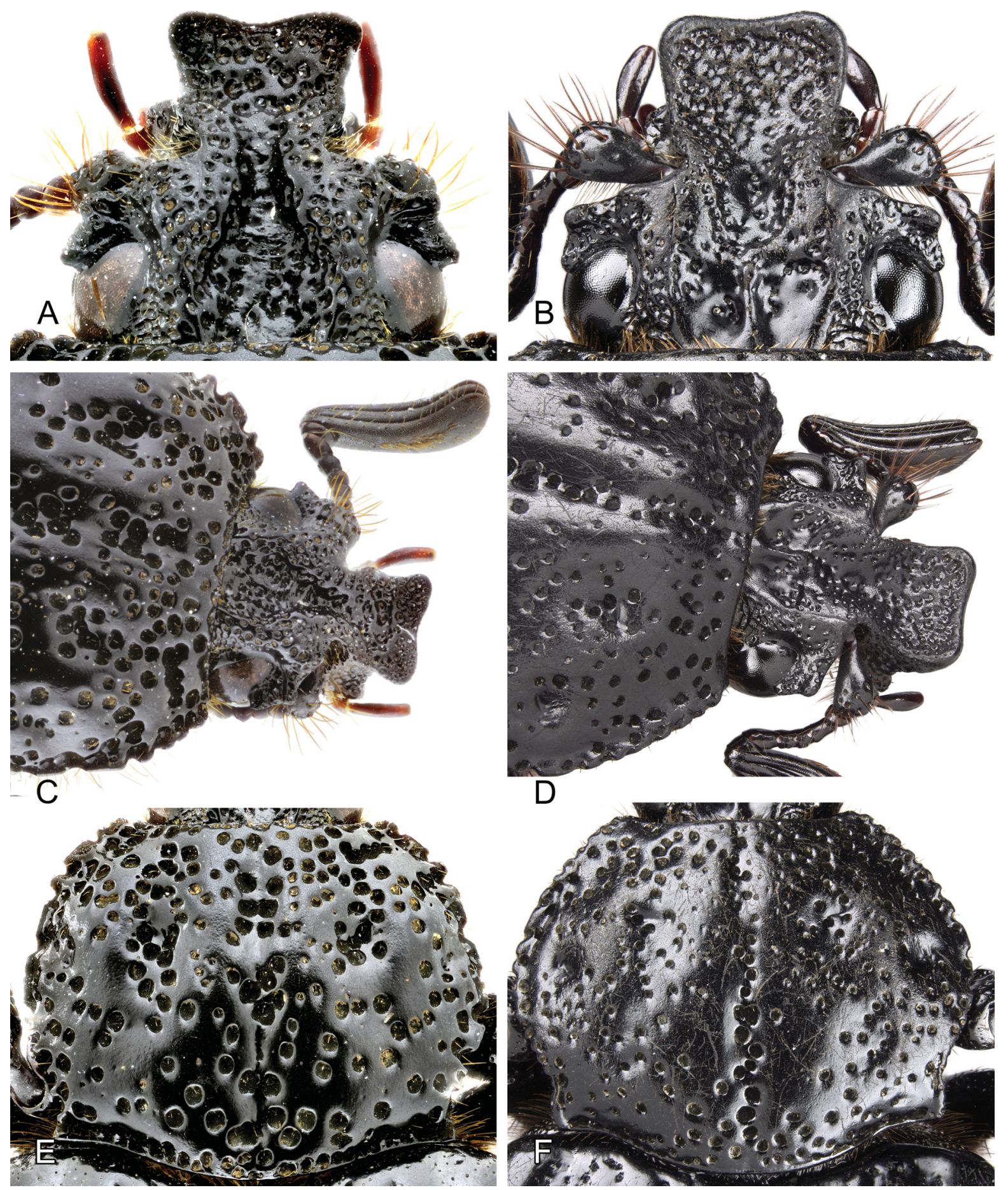

Fig. 2. Details of Archedinus spp. A, C, E-A. antoshkai sp. nov. B, D, F - A. howdeni Morón \& Vaz-de-Mello 2007. A-B - head dorsal view. C-D head antero-lateral view. E-F - pronotum dorsal view. Images 2B,D,F courtesy of François Génier. 
Prothorax. Pronotum about 1.3 times wider than long; 1.5 times wider at posterior angles than at anterior angles, margins rounded, slightly more strongly convergent to posterior angles (Figs 2C,E). Dorsal surface coarsely and irregularly punctate, punctures more dense in anterior half, punctures deep, ranging from $37-325 \mu \mathrm{m}$ in diameter. Disc with a longitudinal depression on midline, and 2 depressions on each side, 1 large, elongate at anterior half, vanishing towards antero-lateral corners, and a small, shallower one at posterior $3 / 4$, depressions with punctures wider and confluent. Prosternum smooth on sides, with long prosternal process, acute, with briefly rounded apex, and many long, tawny setae projected anteriad.
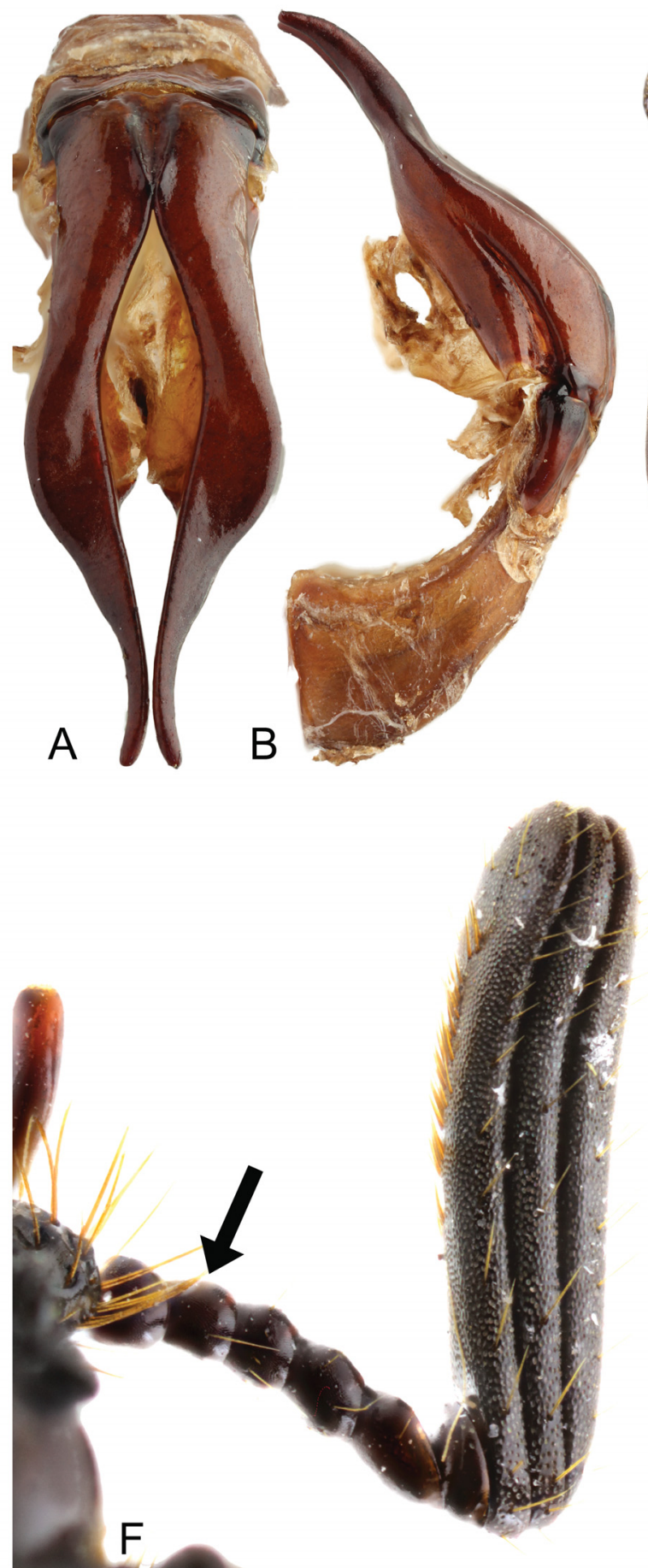

Elytra with margins curved in anterior fifth, then subparallel to rounded apical fourth; with 10 wide, deep striae, each with irregular row of rounded to elongate ellipsoid, foveate punctures; striae I-V extend from anterior border to apical callus; striae VI-IX extend from humerus to apical umbone; stria $\mathrm{X}$ extends along lateral margin but does not reach apex; interstriae shiny, with fine punctures and sparser, larger, foveate punctures; epipleura continuously narrowing posteriorly to just before apex. Mesothorax. Mesoventrite coarsely punctate, depressed at center, abruptly upturned near anterior borders of mesocoxae. Wings well developed. Metaventrite convex at sides, moderately depressed around discrimen; coarsely punctate towards anterolateral corners
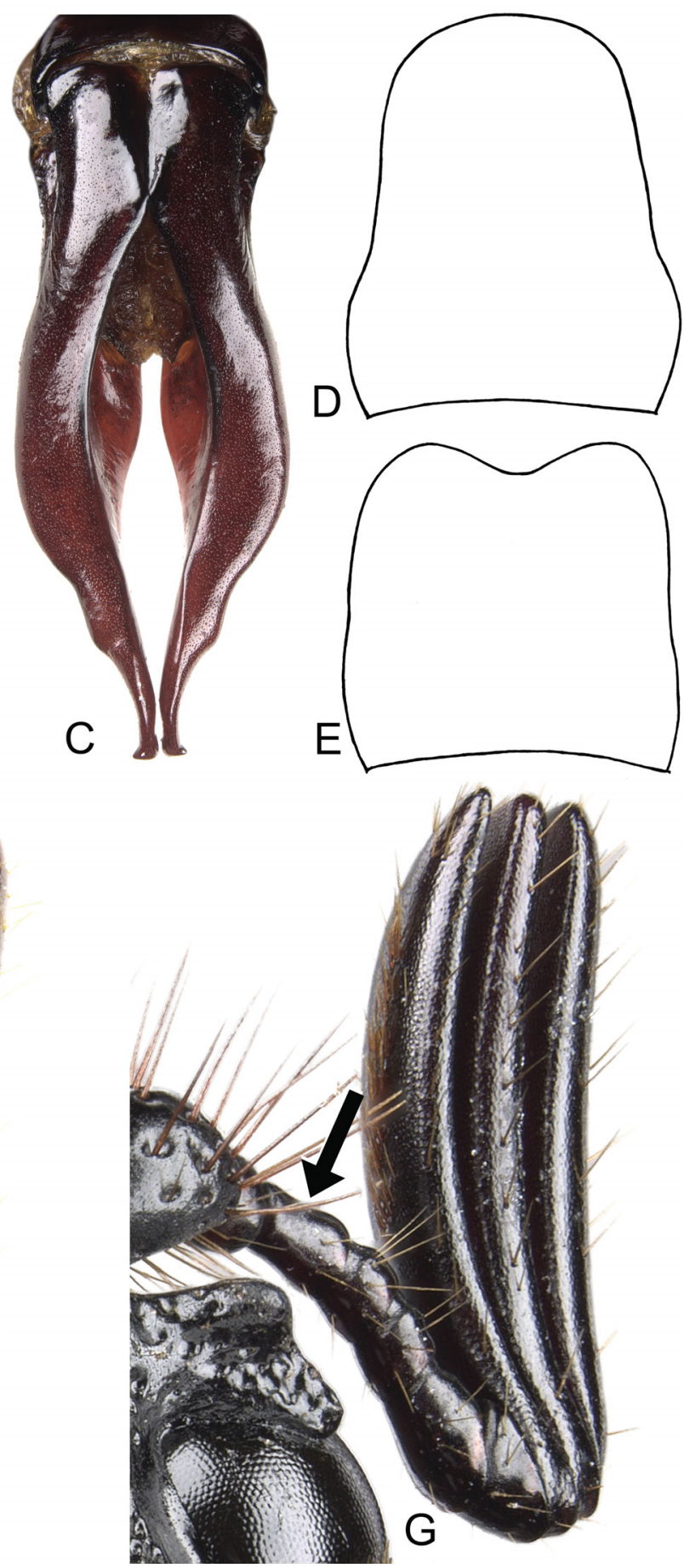

Fig. 3. Details of Archedinus spp. A, B, D, F-A. antoshkai sp. nov. C, E, G - A. howdeni Morón \& Vaz-de-Mello 2007. A, C-aedeagus dorsal view. B aedeagus lateral view. D-E - outline of mentum. F-G - antennae with arrow indicating third antennomere. Images 3C,G by courtesy of François Génier. 


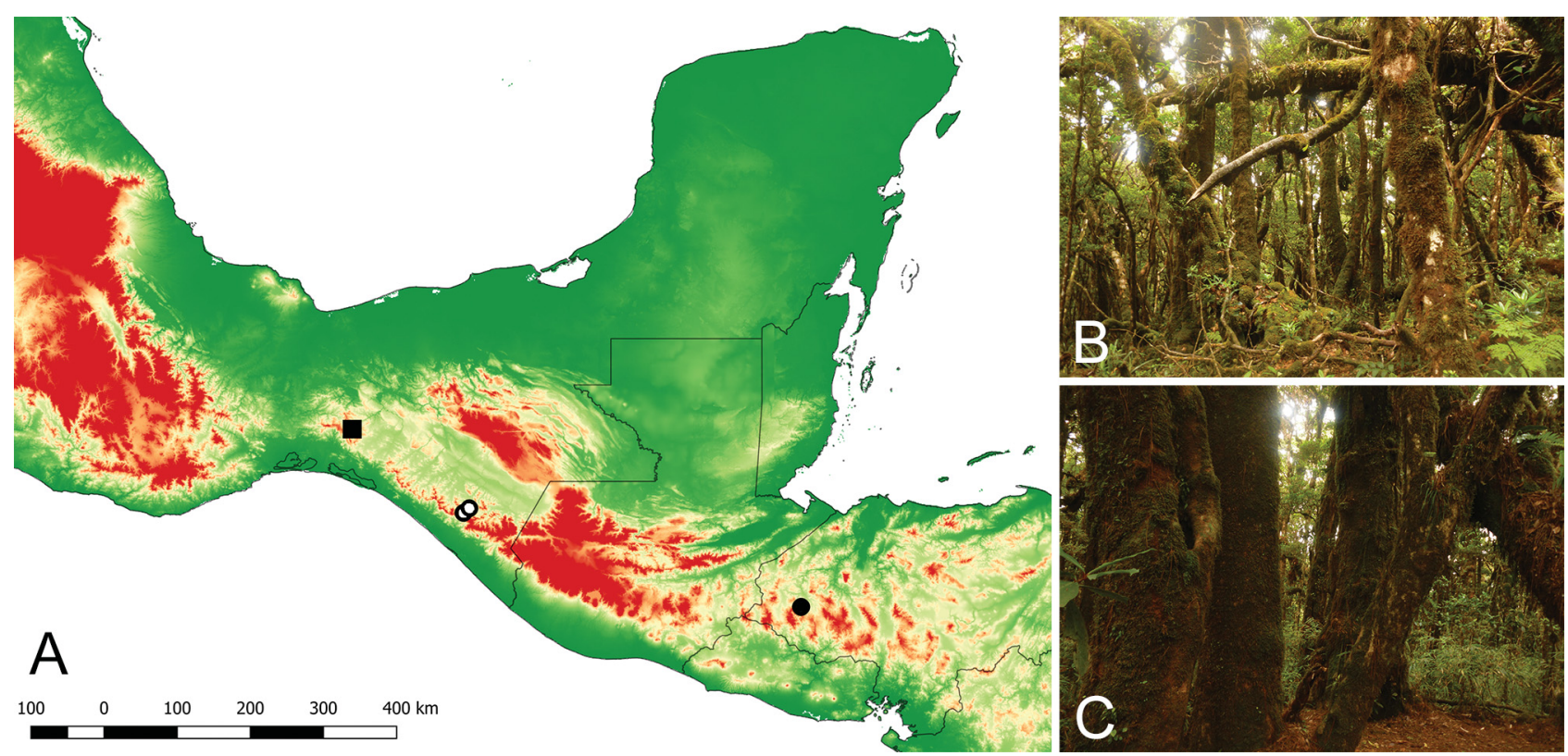

Fig. 4. Distribution and habitat Archedinus species. A - distribution map: black square - A. relictus Morón \& Krikken, 1990; white circle - A. howdeni Morón \& Vaz-de-Mello, 2007; black circle - A. antoshkai sp. nov. B-C - type locality of A. antoshkai sp. nov. in Celaque National Park at 2600 m. Images $4 \mathrm{~B}-\mathrm{C}$ by courtesy of Viktor Sinyaev.

with many slender, decumbent to erect setae. Legs. Profemur with a preapical, blade-like, dorsal projection, with rounded apex. Protibia with a wide inner basal notch. All tarsi robust, with large, sickle-shaped claws.

Abdomen. Ventrites convex, almost glabrous, with sparse, small decumbent setae, finely punctate, punctures narrowly transverse; last ventrite with deeper, more rounded punctures on posterior margin which is slightly raised and briefly emarginate at middle. Pygidium glabrous, shiny, with dense, fine micropunctures mixed with sparse, large, sometimes confluent, round punctures, finely rugose toward basal angles; without waxy spots; posterior margin nearly rounded. Genitalia. Aedeagus with large basal piece, slightly convex; tectum shallowly concave; parameres elongate, sinuous in lateral view, with apical third bifurcate in apical third in dorsal view, apex rounded (Figs 3A-B).

Female. Unknown.

Differential diagnosis. Archedinus antoshkai is most similar to $A$. howdeni based on the emarginate clypeal projection, anterior prosternal process with rounded apex, and the apices of the parameres not being bifurcate. However, it can be distinguished from it by its smaller size ( $17.5 \mathrm{~mm}$ in A. antoshkai versus $25-27 \mathrm{~mm}$ in $A$. howdeni), the clypeal projection with anterior margin more strongly emarginate medially (Fig. 2A in $A$. antoshkai versus Fig. 2B,D in $A$. howdeni), in A. howdeni the frons is with an elongate, triangular depression (Figs 2A,C in A. antoshkai versus Fig. 2B in A. howdeni), the third antennomere is small, being as long as the fourth (Fig. $3 \mathrm{~F}$ in $A$. antoshkai versus Fig. $3 \mathrm{G}$ in $A$. howdeni), the mentum is elongate with a rounded anterior margin (Fig. 3D in A. antoshkai versus Fig. 3E in $A$. howdeni), pronotum with coarser lateral margins (Figs 2C,E in A. antoshkai versus Figs 2D,F in A. howdeni) and the aedeagus with apices of the parameres simple, without a small lateral projection (Fig. 3A in A. antoshkai versus Fig. 3C in A. howdeni).
Etymology. The new species is named after Anton Olegovich Kozlov (Moscow, Russia), who made the specimen available for study and generously donated the holotype to us. The name refers to the diminutive form of his first name, "Antoshka", used by friends; noun in apposition.

Natural history. The species occurs in the highest mountain in Honduras in a tropical cloud forest at $2600 \mathrm{~m}$ elevation. Female specimens, immature stages, and life cycle are unknown.

Distribution. Only known from the type locality: Cerro Las Minas in Celaque National Park, Lempira Department, Honduras.

Key to the males of Archedinus

(modified from Morón \& VAZ-DE-Mello 2007)

1 Apex of prosternal process acute. Profemur with an acute preapical tooth. Elytral striae with waxy gray secretion. Male clypeus with short, bifurcate horn. Apex of parameres bifurcate.

A. relictus Morón \& Krikken, 1990

- Apex of prosternal process rounded. Profemur with a rounded preapical tooth. Striae without waxy secretion. Male clypeus with elevated anterior margin briefly sinuate. Apex of parameres acute.

2

2 Antennomere 3 as long as antennomeres 4 and 5 combined. Mentum short and anteriorly sinuate. Apex of parameres with small, lateral projection. Total length 25-27 mm.

A. howdeni Morón \& Vaz-de-Mello, 2007

- Antennomere 3 half as long as antennomeres 4 and 5 combined. Mentum elongate and anteriorly rounded. Apex of parameres simply rounded. Total length ca. $17.5 \mathrm{~mm}$. ........ A. antoshkai Seidel \& Arriaga-Varela sp. nov. 


\section{Catalogue of the tribe Incini}

Tribe Incini Burmeister, 1842

Incadae Burmeister, 1842: 704 [original spelling]

Type genus. Inca LePeletier \& Serville, 1828.

Remarks. BOUCHARD et al. (2011) corrected the stem of the family group name from Inca- to Inc-, lacking an explanation for their action. As discussed below under the section Inca, Inca is a masculine genus name derived from Spanish. While creating family-group names BURMEISTER (e.g., 1842, 1844) removed a few final letters from every genus name independently from their gender and added suffixes such as -idae, -didae or -adae (e.g., Lomapteridae Burmeister, 1842 [from Lomaptera Gory \& Percheron, 1833]; Macraspididae Burmeister, 1844 [from Macraspis MacLeay, 1819]; Lichniadae Burmeister, 1844 [from Lichnia Erichson, 1835]). Therefore, it can be securely assumed that the correct stem of Incadae Burmeister, 1842 is Inc- and Article 29.3.3. (ICZN 1999) is followed: "If a generic name is or ends in a word not Greek or Latin, or is an arbitrary combination of letters, the stem for the purposes of the Code is that adopted by the author who establishes the new family-group taxon, either the entire generic name (see Article 29.6), or the entire generic name with the ending elided, or the entire generic name with one or more appropriate linking letters incorporated in order to form a more euphonious family-group name".

\section{Genus Archedinus Morón \& Krikken, 1990}

Archedinus Morón \& Krikken, 1990: 74 [original description]

Type species. Archedinus relictus Morón \& Krikken, 1990 [by original designation].

Gender. Masculine.

Species included. 3 species.

Distribution. The genus is found in Mexico and Honduras, likely occurring in Guatemala as well.

\section{Archedinus antoshkai Seidel \& Arriaga-Varela sp. nov.}

(Figs 1A; 2A,C,E; 3A-B,D,F)

Archedinus antoshkai Seidel \& Arriaga-Varela sp. nov. (this paper).

Locality records. HONDURAS: LEMPIRA (this paper).

Types. Holotype in NMPC (Figs 1A; 2A,C,E; 3A-B,D,F).

\section{Archedinus howdeni Morón \& Vaz-de-Mello, 2007}

(Figs 1B; 2B,D,F; 3C,G)

Archedinus howdeni Morón \& Vaz-de-Mello, 2007: 111 [original combination]

Locality records from literature. MEXICO: OAXACA (MORÓN \& VAZ-DE-MeLLo 2007).

Types. Holotype and 1 paratype in MXAL/IEXA, 1 paratype in CMNC (Figs 1B; 2B,D,F; 3C,G), 1 paratype in CEMT (Morón \& VAZ-DE-MeLLo 2007).

\section{Archedinus relictus Morón \& Krikken, 1990} (Figs 5A-B)

Archedinus relictus Morón \& Krikken, 1990: 74 [original combination]

Locality records from literature. MEXICO: CHIAPAs (MORón \& KRIKKEN 1990).

Types. Holotype $\delta$, allotype $q$ and 2 paratypes $\left(\begin{array}{lll}1 & \delta & q\end{array}\right)$ in MXAL,
3 paratypes $\left(2 \hat{\delta} 1+\right.$ ) in SMF (Figs 5A-B), 2 paratypes $\left(1 \hat{\delta} 1_{+}^{\circ}\right)$ in RMNH (MORÓN \& KRIKKEN 1990).

\section{Genus Coelocratus Burmeister, 1842}

Coelocratus Burmeister, 1842: 767 [original description]

Coleocratus: MoRón \& VAZ-DE-MELLo (2007): 118 [incorrect subsequent spelling]

Type species. Inca rufipennis Gory \& Percheron, 1833 [by monotypy].

Gender. Masculine.

Species included. 1 species.

Remarks. BlACKWELDER (1944) and KRAJCIK (1999, 2012) erroneously listed 1841 instead of 1842 as the year of description of the genus. RICCHIARDI (2002) transferred the genus from Trichiini to Incini.

Distribution. According to Gory \& Percheron (1833), Coelocratus rufipennis is from Brazil, but they did not provide a more detailed locality, and BURMEISTER (1842) restricted it to northern Brazil. Actual specimens in the Burmeister collection (MLUH) are labelled as being from Cayenne (French Guiana) (Fig. 6).

\section{Coelocratus rufipennis (Gory \& Percheron, 1833) (Figs 5 C-D)}

Inca rufipennis Gory \& Percheron, 1833: 109 [original combination] Ynca rufipennis: LAPORTE (1840): 159 [combination with misspelled genus name]

Coelocratus rufipennis: BURMEISTER (1842): 768 [new combination]

Types. Lectotype $\delta$ in MNHG (Figs 5C-D) (designated by RICCHIARDI 2002: 4), 1 paralectotype in MACN (invalid lectotype designation by Di IORIO 2013: 82).

Locality records from literature. BRAZIL (GORY \& PERCHERON 1833, BURMEISTER 1842).

Additional material examined. FRENCH GUIANA: CAYENnE: 1 1 (MLUH): Cayenne.

Remarks. As noted by MACLEAY (1838) the author of the species is Gory \& Percheron (1833) and not Dupont as stated in Gory \& Percheron (1833). Di Iorio (2013) overlooked the lectotype designation by RICCHIARDI (2002) and designated a lectotype in the Burmeister collection housed in the MACN. RicCHIARDI (2002) validly designated the lectotype based on one syntype of Inca rufipennis housed in the MNHG collection. The syntype sent by Gory \& Percheron to Burmeister in Argentina therefore has to be regarded as a paralectotype.

\section{Genus Golinca Thomson, 1878}

Golinca Thomson, 1878: 31 [original description]

Type species. Cetonia bifrons Olivier, 1789: 82 [by original designation].

Gender. Masculine.

Species included. 4 species.

Remarks. When describing Golinca, THOMson (1878) did not state the gender of the genus name and as such it has not been subsequently established with the combination of specific epithets. We assume that Thomson derived Golinca from the generic names Goliathus and Inca, two genera of which Incini species were previously combined with. Therefore, the gender of the genus should be regarded as masculine, like in Inca (see above). 
Distribution. The genus is found in Bolivia, Brazil, Colombia, Costa Rica (SoLís 2007), Ecuador, French Guiana, and Peru (Fig. 6).

Examined material not identified to species. BOLIVIA: SANTA CruZ: 1 (PDPC): Bolivia, Sara province, J. Steinbach leg. BRAZIL: AMAzonas: 3 우 (ZMUH): Brazil, Manaus, Rio Negro; 3 우 (ZMUH): Brazil, Uypiranga, Amazone; 1 (MZSP) Brazil, Amazonas, Manaus, Rio Negro, vi.1921, J. F. Zikán leg., 1 (MZSP): Brazil, Amazonas, Manaus, Reserva Ducke, viii.1965. V. C. Araujo leg. МАто Grosso: 1 (USNM): Brazil, Mato Grosso, 1886. COLOMBIA: HuILA: 1 (DBPC): Colombia, Huila, Gigante, viii.1992; 1 (RBINS): Colombia, Huila, Gigante, P. Bleuzen leg. NARIÑo: 11 (DBPC): Colombia, Nariño, v.2002. COSTA RICA: Puntarenas: 1 spec. (MNCR): Costa Rica, Osa, Sierpe, Rancho Quemado, 8.679096, -83.566714, 30.xi.1991, Freddy A. Quesada leg., Número de catálogo: 346020; 1 spec. (MNCR): Costa Rica, Area de Conservación Osa, Golfito, Parque Nacional Corcovado, Estación Sirena, Playa Sirena, 8.480171, -83.591289, 30.xi.1993, Gilberto Fonseca leg., Número de catálogo: 1957850. ECUADOR: PastaZa: 1 1 (DBPC): Ecuador, Pastaza, Puyo, iv.1994; 1 (MSPC): Ecuador, Pastaza, Puyo, ca. 2011. PERU: 2 우 (ZMUH): Peru, Nypiranga, coll. Le Moult; 1 (ADPC): Peru, Rio Huallaga, xi.-xii.1980. A. Bonc Haas leg. Loreto: 1 q (MSPC): Peru, Loreto, Iquitos, 10.i.2007; 11 q (ZMUH): Peru, Iquitos, San-Roque. SAN MARTIN: 306 (PDPC): Peru, San Martin, Altomayo, Naranjos, iii.2017. UCAYALI: 2 우 (PDPC): Peru, Ucayali, Atalaya, i.2017.

\section{Golinca bifrons (Olivier, 1789)}

(Figs 5H-J)

Cetonia bifrons Olivier, 1789: 82 [original combination]

Inca bifrons: LePELETIER \& SERVILLE (1828): 381 [new combination]

Ynca bifrons: LAPORTE (1840): 158 [combination with misspelled genus name]

Golinca bifrons: Tномsом (1878): 31 [new combination]

Locality records from literature. COLOMBIA: AMAZONAS (OtAvo et al. 2013). ECUADOR: Pastaza (CAmpos 1921). FRENCH GUIANA: Cayenne (Olivier 1789).

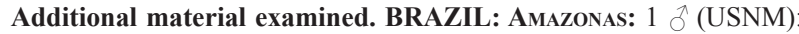
Brazil, Amazonas, Maues, 1934; 1 क (USNM): Brazil, Amazonas, Maues, v.1939; 1 o (USNM): Brazil, Amazonas, Ipiranga, iv.1936. COLOMBIA: HuILA: 1 (SLPC): Huila prov., Gigante, 15.ii.2007. FRENCH GUIANA: CAYENNE: 1 (NMPC): Cayenne; 7 o 7 우 (DBPC): French Guiana, piste Belizon, ii.2005; 2 우 (DBPC): French Guiana, near Cacao, ii.2009; 2 우 (DBPC): French Guiana, piste Regina, xii.2009; 1 1 (ARPC): French Guyana, Matiti ZA Wayabo, i.2015, Jean Louis Giuglaris leg.; $1 \hat{\jmath}$ (PDPC): French Guiana, Montagne de Kaw, PK29 +1(D6), ii.2006, Bondil F. leg.; 1 (PDPC): French Guiana, Crique Blanche, PK 59,5+1 (N2), ii.2009; 1 1 1 (PDPC): French Guiana, piste de Kaw, 26.i.2017; 1 (BCRC): French Guiana: Montagne des Chevaux, RN2, PK 22, xii.2014, S. Brule leg.; 1 (BCRC): French Guiana: Montagne des Chevaux, RN2, PK 22, ii.2012, P.-H Dalens leg.; 1 क (BCRC): French Guiana: Montagne des Chevaux, RN2, PK 22, xii.2011; 3 어의 (CMNC): French Guiana, Piste de Saint Elie, PK32, i.2000, banana trap, Y. Ponchel leg.; 1 \& (ZMUH): Guyana, Cayenne; $1 \lesssim$ (ZMUH): Cayene, coll. Madon. Saint-Laurent-duMAroni: 10 की 5 우 (ZMUH): French Guiana, Nouveau Chantier, collection Le Moult; 3 के 8 오 (ZMUH): French Guiana, St-Jean du Maroni, collection Le Moult.

Remarks. ОтаVо et al. (2013) erroneously listed the year of publication for this species as Olivier, 1758.

\section{Golinca davisii (Waterhouse, 1877)}

Inca davisii Waterhouse, 1877: 228 [original combination] Golinca davisi: ScHENKLING (1922): 5 [new combination and incorrect subsequent spelling]

Locality records from literature. PERU (WATERHOUSE 1877). Additional material examined. BOLIVIA: SANTA Cruz: 1 i 1 (CMNC): Bolivia, Santa Cruz, Ichilo, Steinbach leg.; $1 q$ (CMNC):
Bolivia, Santa Cruz, Ichilo, Buenavista, ii.1950, Martínez leg.; 1 (CMNC): Bolivia, Santa Cruz, Ichilo, Buenavista, iii.1955, Martínez leg. ECUADOR: EL ORo: 19 (MNCN): St. Rosa (Ecuador), 24.v.-5.vi.1865, F. Martinez, Expedicion al Pacifico (1862-1865). Morona SAntiago: 1 (NMPC): Ecuador, Macas, Normandie, $1500 \mathrm{~m}$.

Types. Female holotype in BMNH

Remarks. SchenkLing (1922), while transferring Inca davisii Waterhouse, 1877 to the genus Golinca, misspelled the specific epithet as "davisi" lacking one " $i$ ". This incorrect subsequent spelling has since been used by several authors (Bergé 1884, BlaCKWELder 1944, KRAJCIK 1999, Morón \& Vaz-de-Mello 2007, Valois \& Silva 2015). Nevertheless, the correct spelling, G. davisii, remained in use (Nagai 1994, Ratcliffe et al. 2015, De Souza Silva et al. 2017). We follow Art. 33.3 (ICZN 1999) which states that "any subsequent spelling of a name different from the correct original spelling, other than a mandatory change or an emendation, is an "incorrect subsequent spelling"; it is not an available name". Since both the correct and incorrect subsequent spellings were recently in use, the incorrect subsequent spelling is not in prevailing usage and cannot be preserved under Art. 33.3. The name to be used is Golinca davisii (Waterhouse, 1877).

\section{Golinca ishiharai Nagai, 1994}

Golinca ishiharai Nagai, 1994: 243 [original combination]

Types. Holotype in MNHY, 1 paratype in TMPC, 1 paratype in KSPC (NAGAi 1994).

Locality records from literature. PERU: SATIPO (NAGAI 1994).

Remarks. The holotype of G. ishiharai was not found in the MNHY and possibly could have been destroyed by a fire that consumed Shinji Nagai's personal collection (pers. comm. by Kyohei Watanabe, 2018).

\section{Golinca trevisani Valois \& Silva, 2015}

Golinca trevisani Valois \& Silva, 2015: 193 [original combination]

Types. Holotype in MPEG, 1 paratype in BCRC (VALOIS \& SiLVA 2015)

Locality records from literature. BRAZIL: RoNDôNIA (VALOIS \& SILVA 2015), Amazonas (Valois \& Silva 2015).

\section{Genus Inca LePeletier \& Serville, 1828}

Inca LePeletier \& Serville, 1828: 380 [original description] Ynca Chevrolat, 1833: unpaginated [unjustified emendation]

Type species. Cetonia ynca Weber, 1801 [subsequent designation by Howden (1968: 12)]

Gender. Masculine.

Remarks. The authorship and date of publication of the name Inca has been the subject of confusion. BLACKWELDER (1944), Morón et al. (1997), KRAJCIK (1999) and RESTREPO-GIRALDO et al. (2003) erroneously attributed the authorship of Inca to "Serville (1825)". BousQuET (2016) showed that the second livraison of the "Encyclopédie méthodique" containing pages 345 to 832 was published in December 1828. The authors of Inca are LEPELETIER \& SeRVILLE (1828) as stated on page 346 in the second livraison. KraJCIK (1999) erroneously listed Ynca as a synonym to Inca and attributed authorship to Gory \& PERCHERON 
(1833). However, the name Ynca was introduced by CHEvROLAT (1833) as an unjustified emendation and later used by LAPORTE (1840).

LePeletier \& Serville (1828) did not explain the origin and gender of the genus name. Furthermore, the specific epithets associated with the genus in the original description are either gender neutral or can be either masculine or feminine. Since, LePeletier \& Serville (1828) changed the specific epithet "barbicorne" (neutral) to "barbicornis" (masculine and feminine), it is clear that they deemed the gender of the genus not to be neutral. The genus name Inca is derived from the Spanish noun "Inca" (masculine). According to the Diccionario de la Lengua Española (REAL ACADEMIa EsPaÑola 2014) the masculine noun "Inca" has three meanings: 1) sovereign who ruled the Inca Empire; 2) descendant of the Inca; 3) old gold coin of Peru. We follow Art. 30.2.1. (ICZN 1999), which states: "If a name reproduces exactly a noun having a gender in a modern European language (without having to be transliterated from a non-Latin alphabet into the Latin alphabet) it takes the gender of that noun." Since these conditions are met in this case, the gender of the genus Inca is masculine. Furthermore, Burmeister (1842) considered the genus name to be masculine and therefore adapted previously feminine species epithets into the masculine form. The type species of the genus was not selected until Howden (1968) designated Cetonia ynca Weber, 1801 as type species. Howden (1968) thought that the original specific epithet spelling was "inca" not " $y$ nca" and therefore designated the type species by tautonomy following Art. 68.4 (ICZN). Even though in this case the absolute tautonymy was not met, we follow Art. 69.1.1 (ICZN 1999), which states that: "in the absence of a prior type fixation for a nominal genus or subgenus, an author is deemed to have designated one of the originally included nominal species as type species, if he or she states (for whatever reason, right or wrong) that it is the type or type species, or uses an equivalent term, and if it is clear that that author accepts it as the type species." Therefore, the subsequent designation of Cetonia ynca as type species of Inca by Howden (1968) is valid.

Distribution. Known from Tamaulipas in Mexico through Central and South America to Paraguay and northern Argentina (Fig. 6). There are no records known to us from Venezuela, Guyana, and Suriname, but specimens collected in Trinidad and close to the Venezuela and Suriname borders indicate the genus might well be distributed in those countries.

Examined material not identified to species (I. irroratus/burmeisteri group). BRAZIL: Rio de JANEIRo: 1 (BCRC): Brazil, Rio de Janeiro, Rio Friburgo, x.1983, C. Behduin leg.; 1 क (USNM): Brazil, Serra da Carioca. SAnta Catarina: 1 1 (MZSP): Brasil, Santa Catarina, Joinville, Dirings leg.; 1 (MZSP): Brasil, Santa Catarina, Rio Vermelho, ix.1957; 1 o (MZSP): Brasil, Rio Vermelho, Santa Catarina, xi.1960, Dirings leg.; 1 (MZSP): Brasil, Santa Catarina, Rio Vermelho, i.1952; 1 ( (MZSP): Brasil, Rio Vermelho, Santa Catarina, iii.1949, Dirings leg.; 1 (MZSP): Brasil: Santa Catarina, Timbó; 2018 우 (MZSP): Brasil: Santa Catarina, Timbó, iii.1960, Dirings leg.; 3 o $q$ (MZSP): Brasil: Santa Catarina, Timbó, vi.1969; 1 (MZSP): Brasil: Santa Catarina, Timbó, v.1956. São Paulo: 1 (MZSP): Brasil, São Paulo, (Capital), i.1960, Dirings leg.; 1 (MZSP): Brasil, São Paulo, Pindamonhagaba, Eugênio Lefevre, iii.1963, Exp. Dep. Zoologia leg.; 1 (MZSP): Brasil, São Paulo, Salesópolis, Est. Biol. Boraceia, 1.-4.ii.1973, Vanin leg.

\section{Inca besckii Burmeister \& Schaum, 1840}

Inca besckii Burmeister \& Schaum, 1840: 380 [original combination] Inca beskii: BURMEISTER (1842): 711 [incorrect subsequent spelling, unavailable name]

Inca beskei: Oнаus (1900): 219 [incorrect subsequent spelling, unavailable name]

Inca besckei: SCHENKLING (1922): 3 [incorrect subsequent spelling, unavailable name]

Types. Six specimens (possible syntypes) of Inca besckii in MLUH. No types were found in ZMHB.

Locality records from literature. BRAZIL (BURMEISTER \& SCHAUM 1840), Rio de JANeiro (Ohaus 1900).

Additional material examined. BRAZIL: Minas GeraIs: 1 (CEMT): Brazil, Minas Gerais, Mata do Paraíso, $20^{\circ} 47^{\prime} \mathrm{S} ; 42^{\circ} 51^{\prime} \mathrm{W}$, F. Vaz de Mello leg.; 1 (MZSP): Minas Gerais, Passa Quatro, 915 m, 24.i.1923, J. Zikán leg., Banana Koder; 1 (MZSP): Brazil, Minas Gerais, Viçosa, 648 m, xii.1957, col. E. Amante; 1 (MZSP): Minas (Brazil), Passa Quatro, Faz. Dos Campos, 31.i.1916, J. F. Zikán leg.; 1 (MZSP): Minas Gerais, Virginia, Faz. Dos Campos 1500 m, 9.ii.1916, J. F. Zikán leg. Paraná: 1 (NMPC): Brazil, Parana; 1 (BCRC): Brazil, Parana, Roladia, III; 1 (BCRC): Brazil, Parana, Caviuna, XII; 1 1 1 (AKPC): Brazil, Parana, i.2007; 1 (CMNC): Brazil, Campina Grande nr. Curitiba, 15.ii.1966; H. \& M. Townes leg.; 1 (ZMUH): Parana, Curitiba; $2 \delta^{\lambda} 1$ ( $(\mathrm{ZMUH})$ : Brazil, Parana, Lucena. Rio DE JANEIRo: 1 (MZSP): Brazil, Rio de Janeiro, Itatiaya, 1100 m, Maromba, 18.ii.1939, J. F. Zikán leg.; 2 (BCRC): Brazil, Rio de Janeiro, Itatiaya, ii.1969; 1 (NHRS): Rio de Janeiro, Petropolis, 19.xi.1904, F. Ohaus; 1 (NHRS): Rio de Janeiro, Petropolis, 2.ii.1899, F. Ohaus; 1 (NHRS): Rio de Janeiro, Petropolis, 12.i.1899, F. Ohaus. Rıo Grande do Sul: 1 (MZUEFS): Brazil, Rio Grande do Sul, Vila Olivia, 14.ii.1950, J. Becker leg. (\#30591); 1 (MZUEFS): Brazil, Rio Grande do Sul, Vila Olivia, 14.ii.1950, J. Becker leg. (\#30599). Santa Catarina: 1 o (ARPC): Brazil, Santa Catarina, Corupá, iii.1966; 1 (MSPC): Brazil, Santa Catarina, iii.2004; 1 (ARPC): Brazil Santa Catarina, Rio Natal, xii.1975; 1 (MZSP): Brazil, Santa Catarina, Rio Vermelho, vi.1961, Dirings leg.; 3 o (BCRC): Brazil, Santa Catarina, Rio Vermelho, III; 2 ô (BCRC): Brazil, Santa Catarina, 1980; 1 (BCRC): Brazil, Sao Bento do Sul; 1 (MZSP): Brasilien, Santa Catarina, Nova Teutonia, ii.1935, B. Pohl leg.; 1 ( 1 (USNM): Brazil, Santa Catarina, Nova Teutonia, ii.1965; 11 (USNM): Brazil, Santa Catarina, Nova Teutona, iii.1974; 1 1 (USNM): Brazil, Santa Catarina; 1 (CMNC): Brazil, Santa Catarina, Corupá, xi.1977; 2 do 1 q (CMNC): Brazil, Santa Catarina, Jaraguá, iii.1963; Maller leg.; 1 (CMNC): Brazil, Santa Catarina, Mafia, iv.1974, W. Johnson leg.; 1 (ZMUH): Santa Catharina.

Remarks. Schenkling (1922), BlackWelder (1944), KrajciK $(1999,2012)$ and Morón \& VAZ-DE-Mello (2007) erroneously listed Schaum as the only author.

\section{Inca bonplandi (Gyllenhal, 1817)}

Trichius bonplandi Gyllenhal, 1817: 196 [original combination] Inca serricollis (partim): GoRY \& PERCHERON (1833): 108 [I. bonplandi synonymized with $I$. serricollis ignoring priority]

Inca bonplandi: BURMeISTER \& SCHAUM (1840): 380 [new combination and resurrection of the senior synonym]

Ynca bonplandi: LAPORTE (1840): 159 [combination with misspelled genus name]

Inca bomplandi: BRuch (1911): 216 [incorrect subsequent spelling, unavailable name]

Inca tapujo Perty, 1830. Junior subjective synonym.

Inca tapujo Perty, 1830: 51 [original combination]. Synonymized with I. serricollis by GORY \& PERCHERON (1833: 108).

Ynca tapago: LAPORTE (1840): 159 [combination with misspelled genus name and incorrect subsequent spelling of specific epithet, unavailable name]

Inca tapayo: Gory \& Percheron (1833): 108, 401 [incorrect subsequent spelling, unavailable name]

Inca bonplandi var. tapujo: SchENKLING (1922): 4 [downgraded to variety, unjustified act] 
Inca serricollis LePeletier \& Serville, 1828. Junior subjective synonym. Goliath serricollis: DEJEAN (1821): 61 [nomen nudum, unavailable name] Inca serricollis LePeletier \& Serville, 1828 [original combination]. Synonymized with $I$. bonplandi and incorrectly treated as senior synonym by GORY \& PERCHERON (1833: 108); priority corrected by BURMEISTER \& SCHAUM (1840: 380).

Ynca servicollis: LAPORTE (1840): 159 [combination with misspelled genus name; incorrect subsequent spelling, unavailable name]

Goliathus fasciatus Kirby, 1819. Junior subjective synonym.

Goliathus fasciatus Kirby, 1819: 407 [original combination]. Synonymized by Burmeister \& SCHAum (1840: 380).

Inca fasciata: BLACKWELDER (1944): 260 [new combination, incorrect gender agreement]

Goliathus inscriptus Kirby, 1819. Junior subjective synonym.

Goliathus inscriptus Kirby, 1819: 407 [original combination]. Synonymized by Burmeister \& SCHAum (1840: 380).

Inca bonplandi var. inscriptus: ScHENKLING (1922): 4 [downgraded to variety, unjustified]

Inca bonplandi v. inscripta: BLACKWELDER (1944): 260 [incorrect gender agreement]

Goliathus tricuspis Drapiez, 1820. Junior subjective synonym.

Goliathus tricuspis Drapiez, 1820: 272 [original combination]. Synonymized by Burmeister \& SCHAum (1840: 380$)$.

Types. Inca bonplandi: One male syntype in NHRS and one female syntype in UUZM. Inca tapujo: Seven specimens of Inca bonplandi are deposited in ZSM and could be syntypes of I. tapujo (SCHERER 1983). Goliathus inscriptus: One male syntype in BMNH. Goliathus faciatus: one male syntype in BMNH. The types of Inca serricollis and Goliathus tricuspis were not located by us.

Locality records from literature. ARGENTINA: JuJUY (BRUCH 1911), Misiones (Bruch 1911, Richter 1913, Di Iorio 2013). BOLIVIA (Di Iorio 2013). BRAZIL (Gyllenhal 1817; Kirby 1819): Brasilia (Evangelista Neto et al. 2017), Minas Gerais (Perty 1830, Puker et al. 2014), Pará (Schulz 1901), Rio de Janeiro (Drapiez 1820, Ohaus 1900, Costa et al. 1988, Di Iorio 2013). PARAGUAY: CaAguazú (Di Iorio 2013), ITAPÚA (Di IORIO 2013).

Additional material examined. ARGENTINA: Misiones: $2 \lesssim 10$ (NMPC): Argentina, Misiones, Iguazú, xii.99; 1 (NMPC): Argentina, Misiones, Pozo Azul, xii.99; $1 \curvearrowright 1$ (MSPC): Argentina, Misiones, San Pedro, vii.2010; $1 \lesssim 1$ (ARPC): Argentina, Iguazu env.; $1 \lesssim 1 q$ (BCRC): Argentina, Misiones, Mocona, iv.1985. BRAZIL: BRASILIA: 1 (CEMT): Brazil, Distrito Federal, Fazenda Água Limpa, 15²7'26.0"S, 4756'42.3"W, Armd. Isca Abacaxi 1, 28.xii.2013, Evangelista Neto, F. leg.; 1 (MZSP): Distrito Federal, Floresta Cabeça, i.1957, B. Pereira leg.; 1 + (CEMT): Brazil, Distrito Federal, Fazenda Água Limpa, 1557'20.3"S, 47 56'41.5"W, Armd. Isca Banana 12, 13.xi.2013, Evangelista Neto, J. Espírito SANTo: $129 \circ$ (ZMUH): Brazil, Espirito Santo; 19 (DZUP): Brazil, Espirito Santo, Linhares, (P. Sooretema), xii.1969, J. M. Lima leg. (DZUP 273765). Minas Gerais: 1 (NHRS): Minas Geraes, Mar d. Espanha, J. Zikan leg. Paraná: 2 90 (NMPC): Paraná; 1 (ZMUH): Parana, Curitiba; 1 (CEMT): Brazil, Paraná, Londrina, 11.xii.1995, J. Lopes leg.; 1 (ZMUH): Brazil, Parana, Lucena; 1 (MZSP): Brasil,

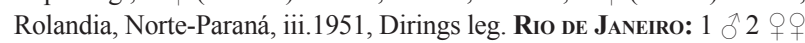
(NMPC): Rio de Janeiro, Havlasa leg; 1 (MZSP): Rio de Janeiro, Itatiaya, 700 m, 17.i.1926, J. F. Zikán leg.; 1 (NMPC): Rio de Janeiro; 1 § 1 , (NMPC): Petrópolis; 1 (NHRS): Rio de Janeiro, Petropolis, 1.ii.1899, F. Ohaus; 1 (NHRS): Rio de Janeiro, Corcovado, 9.i.1899, F. Ohaus; F. Ohaus; 1 (NHRS): Rio de Janeiro, Corcovado, 9.i.1905, F. Ohaus; 1 q (NHRS): Rio de Janeiro, Petropolis, 2.ii.1899, F. Ohaus; 1 (NHRS): Rio de Janeiro, Petropolis, 12.i.1899, F. Ohaus; $1 \hat{\delta}$ (NHRS): Rio de Janeiro, Itatiaya, 27.xi.1926, F. Ohaus. Rio Grande do Sul: 1 (PSPC): Brazil, Rio Grande do Sul; $1 \precsim 1+$ (NMPC): Rio Grande do Sul; 1 (ARPC): Brasil, Rio Grande do Sul, Santa Cruz; 1 (ZMUH): Brazil, P. Alegro; 1 1 (ZMUH): Rio Grande do Sul; 1 (NHRS): Sao Leopoldo, J W. Stahl leg.; 1 ठ(FZBRS): Rio Grande do Sul, S. Luiz Gonzaga, 19.xii.1967, A. C. M. Moraes, (Col. MCN 163. 471); 1 (FZBRS): Rio Grande do Sul, Santa Maria, (Cerrito), 11.ii.1994, L. Witeck leg. (Col MCN 218853); 1 q (MZUEFS): Brazil, Rio Grande do Sul, Vila Olivia, 20.ii.1950, J. Becker leg. (\#30589); 1 (MZUEFS): Brazil, Rio Grande do Sul, 14.ii.1950, J. Becker leg. (\#30598). SANTa Catarina: 1 (NMPC): Santa Catarina. Fu[?] ke leg.; 1 (MZSP): Brasil, Blumenau, Bairro Garoia, Moro Spitzkopf, iii.1962; 1 (MZSP): Brasil, Santa Catarina, Joinville, Dirings leg.; $1 \hat{\jmath}$ (MZSP): Santa Catarina, Nova Teotonio, i.1949, F. Plaumann leg.; 1 q (MZSP): Santa Catarina, Rio Vermelho, i.1958, Dirings leg.; 1 (BCRC): Brazil, Sao Bento do Sul; 1 (ZMUH): Santa Catharina; 1 (MZSP): Brazil, Santa Catarina, Timbó, viii.1963, Dirings leg. São Paulo: 1 ๙ิ (MZUEFS): Brazil, São Paulo, Aguas da Prata 27.ii.1969, J. Becker leg. (\#30592); 1 1 (NMPC): São Paulo, Mráz leg.; 1 (UNSM): Brazil, Sao Paulo, Itaici, i.1960, J. R. Neidoefer leg.; $1+$ (MZSP): São Paulo, Ypiranga; 1 (CMNC): Brazil, Sao Paulo, Capao Bonito, ii.1946, J. Guerin leg.; 1 q (ZMUH): Brazil, Sao Paulo, 1917; 1 q (ZMUH): Brazil, Sao Paulo; 1 q (MZSP): Brasil, São Paulo, Piracicaba, xi.1961, K. Reichardt leg.; 1 q (MZSP): São Paulo, São Sebastião, Praia Baraqueçaba, 2.iv.1963, P. Araujo leg.; 1 (MZSP): Brazil, São Paulo, Sertãozinho, Res. Ecol. Augusto Ruschi, $21^{\circ} 10.520^{\prime} \mathrm{S}, 48^{\circ} 5.47^{\prime} \mathrm{W}, 529$ m, 07-21.xii.2011. Malaise borda, V. C. Silva, P. F. Donda \& G. P. Ignácio leg. PARAGUAY: GuaIRÁ: 1 (NMPC): Paraguay, Villarica, Kolonio Sudetica. ITAPÚA: $2 \approx 1+$ (ARPC): Paraguay, Encarnacion, xii.1975. ITAQUIRI: 1 (DZUP): Paraguai, Itaquiri, 400 m, 15-20.i.1980, Mielke \& Miers leg. (DZUP 273741). SAn Pedro: 122 + 1 (NMPC): Paraguay, Carlos Pfannl, i.1969, José Andres lgt.

Remarks. BLACKWELDER (1944) erroneously attributed authorship of Inca serricollis to GORY \& PERCHERON (1833). SCHENKLING (1922) listed "tapujo" and "inscriptus" as variations of Inca bonplandi (Gyllenhall, 1817), and there seems to be no evident justification for Schenkling's listing. KRAJCIK (1999) incorrectly gave the year for Inca tapujo as 1834 and not 1830. Burmeister \& SCHAum (1840) stated that Goliathus inscriptus Kirby, 1819 only represents an "insignificant variety" and later Burmeister \& SCHAum (1841) added that it is only a darker variant of Inca bonplandi. Goliathus fasciatus Kirby, 1819 and Goliathus tricuspis Drapiez, 1820 were listed by BURMEISTER \& SCHAUM (1840) as synonyms of Inca bonplandi without further comment. Di IORIO (2013) interpreted the synonymical listing of Goliath fasciatus and Goliath inscriptus under Inca bonplandi only as a reference, but we acknowledge that BURMEISTER \& SCHAUM (1840) established these synonymies. Schaum (1849) stated that the type of Goliathus fasciatus Kirby, 1819 only represents a "slight variation" of Inca bonplandi. He clearly intended to keep Kirby's species in synonymy. BLACKWELDER (1944) unjustifiably emended and combined the name to Inca fasciata. Both, Burmeister \& SCHAum (1840) and LAPORTE (1840) resurrected Inca bonplandi as valid name over the junior synonyms, but BURMEISTER \& SCHAUM (1840) was published in July-September 1840 (BOUSQUET 2012), whereas LAPORTE (1840) was published as earliest as on 26 December 1840 (Bousquet 2016). Therefore, BurmeIsTER \& SCHAum (1840) deserve credit for the resurrection.

\section{Inca burmeisteri Burmeister, 1847}

Inca burmeisteri Burmeister, 1847: 568 [original combination]

Types. Three specimens (possible syntypes) of Inca burmeisteri in MLUH. No types were found in ZMHB.

Locality records. BRAZIL (BURMEISTER 1847).

Additional material. BRAZIL: Minas Gerais: $1 \hat{\delta}$ (MZSP): Ouro Preto, 27.xii.1998, F. Ohaus leg. Rio de JANEIRo: 1 (UFRPE): Brasil, Rio de Janeiro, Nova Friburgo, Garrafão, Cascatinha, 23.iii.2003; 1 q (UFRPE): Brasil, Rio de Janeiro, Nova Friburgo, Garrafão, Cascatinha, 6.iv.2002; 1 q (UFRPE): Brasil, Rio de Janeiro, Nova Friburgo, Garrafão, Cascatinha, iii.1999, R. Vassalo leg., Coleção F. \& P. Grossi; 1 స (UFRPE): Brasil, Rio de Janeiro, Nova Friburgo, Garrafão, Cascatinha, 27.iii.2004, R. Vassalo leg. 
Remarks. KRAJCIK (1999) erroneously listed "I. irrorata Burmeister, 1842" as a synonym of I. burmeisteri, but BURMEISTER (1842) only redescribed I. irroratus Chevrolat, 1833 based on a missidentification and is not the author of the name. Burmeister (1847) clarified that his 1842 redescription was actually based on I. burmeisteri specimens.

\section{Inca clathratus clathratus (Olivier, 1792)}

(Figs 5E-F)

Cetonia clathrata Olivier, 1792: 93 [original combination] Trichius clathratus: ScHÖNHERR (1817): 100 [new combination] Inca clathratus: SCHAUM (1844): 399 [new combination]

Inca fabricii Perty, 1830. Junior subjective synonym.

Inca fabricii Perty, 1830: 51 [original combination]. Synonymized with I. weberi by Burmeister \& Schaum (1840: 379).

Ynca fabricii: LAPORTE (1840): 158 [combination with misspelled genus name]

Inca weberi LePeletier \& Serville, 1828. Junior objective synonym.

Inca weberi LePeletier \& Serville, 1828: 381 [unjustified replacement name for Cetonia ynca]. Synonymized with I. ynca by GoRY \& Percheron (1833: 103), with I. clathratus by Schaum (1844: 399).

Cetonia ynca Weber, 1801. Junior subjective synonym.

Cetonia ynca Weber, 1801: 66 [original combination]. Synonymized with I. clathrathus by SCHAUM (1844: 399).

Inca ynca: Gory \& Percheron (1833) :103 [new combination]

Types. Cetonia clathrata: Syntypes are probably in MNHN since Olivier's collection is deposited there. Inca fabricii: One specimen is deposited in ZSM and could be a syntype (SCHERER 1983). Cetonia ynca and Inca weberi: Types were not found in the Zoologisches Museum in Kiel (pers. comm. by Michael Kuhlmann).

Locality records from literature. ARGENTINA: JUJUY (DI IORIO 2013), Misiones (Bruch 1911, Hayward 1935-1936, Di Iorio 2013), Salta (D Iorio 2013). BRAZIL: Minas Gerais (Perty 1830). COLOMBIA: Valle del Cauca (Restrepo-Giraldo et al. 2003). ECUADOR: Bolívar (CAmpos 1921). FRENCH GUIANA: Cayenne (Olivier 1792). GUIANA(Bates 1889, Howden 1968). PERU (Weber 1801): Huanuco (Soukup 1942), SAn Martín (Soukup 1942).

Additional material examined. BOLIVIA: Cоснавамва: $1 \hat{\jmath} 19$ (RBINS): Bolivia, Cristal Mayu, 450 m, iv.1984, G. Lecourt leg. SANTA Cruz: 1 (BCRC): Bolivia, Santa Cruz, Los Volcanes Reserve, ii.2013, S. Lingafelter leg.; 1 (CMNC): Bolivia, Santa Cruz, Andrés Ibañez, 24.v.1992, moribundo a los pies de Jasmin [= dying at the feet of Jasmin], Zeballos-Lobo leg.; $1 \succsim$ (CMNC): Bolivia, Santa Cruz, Pua Ichilo, Buenavista, ii.1950, Martínez leg.; 1 (CMNC): Bolivia, Santa Cruz, Puia. Ichilo, Buenavista, Tacú, iii.1951, Martínez leg; 1 (MZSP): Bolivia, Santa Cruz, Abapo, $\left(20 \mathrm{~km} \mathrm{~S}, 1^{\circ} 06^{\prime} \mathrm{S} 63^{\circ} 14^{\prime} \mathrm{W}, 730 \mathrm{~m}\right)$, Clarke \& Zamaloa leg.; 1 (MZSP): Bolivia, tropica, Region Chapare (400 mtr.), v.1953, Dirings leg. BRAZIL: Amapá: 2 $\uparrow$ (MZSP): Brasil, Amapá, Macapá, (Pôrto Platon), x.1964, E. Dente leg. Amazonas: 1 (BCRC): Brazil, Tefe, XI; 1 ठ (ZMUH): Brazil, Manaus, Rio Negro, coll. Le Moult; 1 ( (ZMUH): Brazil, Amazone, Lago Calado, coll. 1 (MZSP): Brasil, Amazonas, Benjamin Constant, Rio Javari, xii.1962, Dirings leg.; 1 q (MZSP): Amazonas, Rio Jaruá, 1901; 1 (MZSP): Amazonas, Taracuá, 1937, Pe. A. Giacomo leg.; 19 (MZSP): Amazonas, Teffé, A. H. Passl leg.; Gounelle; $1 \precsim$ (RBINS): Brazil, Amazonas, Tonantins, 80 m, vii.1993, M. Büche leg. BAHIA: 19 (MZSP): Brasil, Baia, Ilhéus, (Fazenda São Caetano), viii.1959, Dirings leg. BRASILIA: $1 \hat{\jmath}$ (CEMT): Brasil, Distrito Federal, Gama, Eldorado, 07.x.2009, J.A.I. Cordeiro leg. EsPIRITo SANTo: 1 (DZUP): Brasil, Espirito Santo, Linhares, 50 m, iii.1964, (DZUP 273708); 1 (DZUP): Brasil, Espirito Santo, Linhares, 50 m, ii.1964, (DZUP 273705); 1 (DZUP): Brasil, Espirito Santo, Linhares, 50 m, xi.1966, (DZUP 273706); 1 (DZUP): Brasil, Espirito Santo, Linhares, xi.1965, A. Maller leg., (DZUP (273707). Goı́́s: $1 \delta$ (NMPC): Goyaz, Rio Verde; $2 \hat{\jmath}$ (FZBRS): Goiás, Minaçú, Serra da Mesa, 19-30.xi.1996, A. Bonaldo leg., (Col. MCH 238640, 238641); 1 q (MZSP): Goyaz, Pereira Magalhães, leg.; 1 (MZSP): Brasil, Goiaz, Rio Verde; $1 \uparrow(\mathrm{MNCN})$ : Brazil, Goyaz, Rio Verde. Maranhão: $1 \precsim$ (CEMT): Brasil, Maranhão, Bom Jardim, REBIO-Pos. Biol. Gurupi, Arm. Luminosa Móvel, 17-27.i.2010, F. Limeira de Oliveira, M. B. Aguiar-Neto \& A. A.
T. Sousa legs. Mato Grosso: $1 \subsetneq$ (MZSP): Brasil, Mato Grosso, Barra do Tapirapé, 21-31.xii.1965, B. Malkin leg.; 1 (DZUP): Mato Grosso, Chapada dos Guimarães, 23.xi.1983, Exc. Dep. Zool. DZUP col., (Polonoroeste), (DZUP 273725); 1 (MZSP): Mato Grosso, Posto Indigena do Xingu - Posto Diauarum, 2.xi.-11.xii.1973, G. Kloss leg. MAto Grosso Do Sul: $1 \delta 1$ (MZSP): Bata-Porã, Fazenda Primavera, 1.iii.1993, J. Leopoldo leg. Minas Gerais: $1 \oint$ (MZSP): Bresil (Minas), Sertão de Diamantina, Faz. Das Melancias, E. Gounelle leg., 10.ii.1902; 1 (DZUP): Brasil, Minas Gerais, Rio Verde, 40 m, ii.1960, (DZUP 273722). PArá: 1 (DBPC): Brazil, Pará, Óbidos, vi.1994; 2 đ̊ 2 of (MZSP): Brasil, Pará, Km 94, Rodovia Belém-Brasília, i.1963, E. Dente leg.; 1 q (MZSP): Miritituba, Rio Tapajós; 1 1 (RBINS): Amazonas, Obidios, xii. 1935; 1 (RBINS): Amazonas, Obidios, xi.1988. Pernambuco: $1 \lesssim 1$ (DZUP): Brasil, Pernambuco, Caruarú, 900 m, v.1971, Joaquim Lima leg., (DZUP 273715). RondônIA: 1 (DZUP): Rondônia, Vilhena, 5.xii.1986, C. Elias leg., Polonoroeste, (DZUP 273709); 1 † (DZUP): Rondônia, Vilhena, 15.xii.1986, C. Elias leg., Polonoroeste, (DZSP 273714). RoraIMa: 1 (DZUP): Brasil, Roraima, Maracá, 20-26.vi.1988, Mirna \& Mielke, (DZUP 273720); 7 6 + 9 (MZSP): Brasil, Roraima, Ilha de Maracá (Estação Ecológica de Maracá) 03²2.229' N 61²6.648’W, 18-24.v.2015, 143 m, Van Sommeren (fruta), Ponto 7, Biffi, Falaschi, Pinheiro \& Riccardi les. São Paulo: $2 \hat{\jmath}$ (MZSP): Brasilien, São Paulo, Presidente Epitácio, xii.1936, coll. H. Zellibor; 1 đ (MZSP): Brasilien, São Paulo, Presidente Epitácio, ii.1937, B. Pohl leg. COLOMBIA: CaQuetá: $1 \precsim 1$ (SLCC): Caqueta, Amazonas, 12.i.2003, S. Castro leg. HuIla: 1 o 1 (MSPC): Colombia, Huila, Gigante, iv.1988, G. Schulz Vinnh./Han. VAlle DEL Cauca: $1 \delta 1$ (BCRC), Colombia, Valle, $45 \mathrm{~km} \mathrm{~W}$ of Buga, ii.1992; 1 (DBPC): Colombia, Calima valley, $45 \mathrm{~km} \mathrm{~W}$ of Buga, 17.xi.1991; $2 \delta$ 1 (DBPC): Colombia, Calima valley, $45 \mathrm{~km} \mathrm{~W}$ of Buga, 20.ii.1992; 1 (DBPC): Colombia, Buga, Calima valley, xii.1988; 1 (DBPC): Colombia, Buga, Calima valley, vi.1989; $2 \curvearrowright 1$ (RBINS): Colombia, Calima valley, $45 \mathrm{~km}$ West of Buga valley, $1200 \mathrm{~m}$, 18.xi.1991, P. Bleuzen leg. ECUADOR: Bolívar: 2 9 (NMPC): Ecuador, Balsapamba, R. Haemsch leg.; $2 \widehat{\delta} 2$ + $($ USNM): Ecuador, Balzapamba, F. Campos leg. CAÑAR: 2 ก 2 우 (DBPC): Ecuador, Cañar, iii.2002. Los Ríos: 1 (USNM): Ecuador, Los Rios, v.1938; NAPo: 1 (USNM): Ecuador, Napo, Tena (13 km SW), v.1977. Orellana: $1 \curvearrowright$ (DBPC): Ecuador, Coca, v.2001; $9 \lesssim 9$ + (DBPC): Ecuador, environs de Coca, v.2011. PAstaza: 1 (USNM): Ecuador, Pastaza, Puyo, v.1977, P. Spangler leg.; 1 (DBPC): Ecuador, Pastaza, xi.2000. Tungurahua: $1 \precsim 1$ (USNM): Ecuador, Banos, v.1931. FRENCH GUIANA: CAYENNE: 1 (UNSM): French Guiana: Montagne des Chevaux, RN2, PK 22, ii.1969, H. Dalens leg.; 1 (BCRC): French Guiana, Montagne des Chevaux, RN2, PK 22, xii.2014, S. Brule leg.; 1 4 9 (DBPC): French Guiana, Cacao, viii.2009. PERU: 2 q (ZMUH): East of Peru, Nypiranga. Cuzco: 11 (RBINS): Peru, Cuzco, xii.1997, Harald Schulz-Gorbsan leg. Huánuco: 1 (NMPC): Perú, Huánuco, Tingo María, ii.2001, S. \& P. Pokorný leg.; 1 1 1 (MSPC): Perú, Tingo María, viii.2016, E. Picoy leg.; 11 (ARPC): Peru, Huanuco, Tingo Maria, 1993, H. Schulz leg.; 11 (DBPC): Peru, Tingo Maria, Santa Maria district, 670 m, ix.2008; 1 (CMNC): Peru, Huanuco, Tingo Maria, 18.xii.1968, J. Schunke leg. Junín: 1 đ 4 † (NMPC): Perú, Satipo, F. Tippmann leg.; $2 \precsim 1$ (RBINS): Peru, Satipo, 700m, iv.1986, G. Lecourt leg.; 1 1 1 (RBINS): Peru, Satipo, i.1992. LoREto: $1 \precsim$ (MNCN): Peru, Montealegre, Rio Pachitea, G. Tessmann. MAdre de Dios: $1 \lambda$ (DBPC): Peru, Madre de Dios, Povince of Manu, Manu, 545 m. SAn Martín: 5 えठ 5 + (DBPC): Peru, San Martin, Juanjui, xi.2009; 1 (DBPC): Peru, San Martin, Alto Nieva, xi.2011;3 19 (DBPC): Peru, San Martin, Tocache, x.2010; $2 \delta$ (DBPC): Peru, Moyobamba zona affluente; $1 \lesssim 10$ (DBPC): Peru, San Martin, Naranjos, Rioja, zona affluente, xi.2010; 1 (ZMUH):

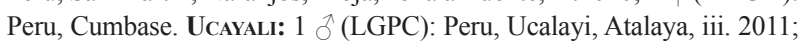
1 (ZMUH): Peru, Ucayali, 1914.

Remarks. Gory \& PERCHERON (1833) erroneously attributed Inca ynca to Fabricius, 1801. But FABRICIUS (1801) clearly attributed the authorship to WEBER (1801). BuRMEISTER \& SCHAUM (1840: 420) stated that they never saw Cetonia clathrata Olivier, 1792 and therefore only listed it at the end of their work. KRAJCIK (1999) listed the year of description of Inca fabricii Perty as 1834 instead of 1830 , but this species was described in the first fascicle on 
page 51 which was published in 1830 (BOUSQuET 2016). LePeletier \& SERVILle (1828) introduced the name Inca weberi for Cetonia ynca Weber, 1801, probably to remove the 'tautonymy' which, for example, is not allowed in botany. Schaum (1844) synonymized Inca weberi LePeletier \& Serville, 1828 with Inca clathratus Olivier, 1792.

\section{Inca clathratus quesneli Boos \& Ratcliffe, 1985}

Inca clathrata quesneli Boos \& Ratcliffe, 1985: 382 Inca clathratus quesneli: [gender agreement corrected here]

Types. Holotype $\delta$, allotype $q$ and paratypes in BMNH (Boos \& RATCLIFFE 1985); paratypes in FSCA, USNM, NHMB, MNHN, CMNC, UNSM, private collections of Julius Boos (deceased) and John Glaser (Baltimore) (Boos \& RATCLIFFE 1985).

Locality records from literature. TRINIDAD (Boos \& RATCLIFFE 1985). Additional material. TRINIDAD: $1 \uparrow$ (USNM): Trinidad, Maracas Bay, June 1969, J. Boos; 1 ( 1 (USNM): Trinidad, Marval

\section{Inca clathratus sommeri Westwood, 1844}

(Fig. 5G)

Inca sommeri Westwood, 1844: 99 [original combination]

Inca clathratus (partim): Schaum (1844: 399), Schaum (1849: 288) [considered as junior synonym of $I$. clathratus]

Inca sommeri: ERICHSON (1845): 108 [species status restored] Inca clathrata sommeri: BATES (1889): 377 [subspecific status established] Inca clathratus sommeri [gender agreement corrected here]

Types. One female syntype in BMNH.

Locality records from literature. BELIZE: CAYo (BATES 1889, Howden 1968). GUATEMALA: Izabal (Howden 1968). MEXICO: Chiapas (Howden 1968, Morón 1983), Hidalgo (Morón 1994), OAXaca (Westwood 1844), Tamaulipas (Reyes-Castillo \& Lara-Villalón 1994), Veracruz (Howden 1968). NICARAGUA: Chontales (Bates 1889, Howden 1968). PANAMA: ChiRiqui (BATEs 1889, Howden 1968). Additional material examined. COSTA RICA: Puntarenas: $2 \pi 2$ (DBPC): Costa Rica, Osa Corcovado, vi.2017; $4 \lesssim 2$ क 9 (DBPC): Costa Rica, Osa Corcovado, vi.2016. BELIZE: Stann CReEk: $1 q$ (UNSM): Belize, Stann Creek, Mayflower National Park, v.2008, B. C. Ratcliffe leg.; $4 \lesssim 2$ o $($ (UNSM): Belize: Stann Creek, Cockscomb Wildlife Sanctuary, v.2008, B. C. Ratcliffe leg.; 1 \& 1 (BCRC): Belize, Stann Creek, Cockscomb Wildlife Sanctuary, v.2008 B. C. Ratcliffe leg. GUATEMALA: Alta Verapaz: 1 (SLCC): Baleu, Mpio San Cristobal, Verapaz, Alta Verapaz, 1350 m., 16.viii.1995. SuCHITEPÉQuEz: $2 \delta \delta$ (ARPC): Guatemala, Suchitepéquez, Santa Barbara, Finca Santa Maria, 7.ix.1997. ZACAPA: $2 \lambda$ 2 O (DBPC): Guatemala, Zacapa, vii.2007. HONDURAS: OLANCHO: 1 spec. (EAPZ): Honduras, Olancho, 14 km N La Unión, 21.x.1995, RD Cave leg., 013824EAPZ. Yoro: 1 (UNSM): Honduras, Yoro, Parque Nacional Pico Bonito, vii.2001, H. Hernandes leg.; 1 (UNSM): Honduras, Yoro, Linda Vista, ix.1989, R. D. Cave leg.; 6 spec. (EAPZ): Guatemala, Yoro, Parque Nacional Pico Bonito, Montaña de Santa Bárbara, 16.ix.2000, A. Hernández leg., [47.285-47.290]EAPZ; 2 spec. (EAPZ): Guatemala, Yoro, Parque Nacional Pico Bonito, Montaña de Santa Bárbara, 7.x.2000, A. Hernández leg., [57.198-57.199]EAPZ; 1 spec. (EAPZ): Guatemala, Yoro, Linda Vista, 10.ix.1999, R. Cave, J. Torres \& R. Díaz leg., 100.032EAPZ; 1 spec. (EAPZ): Guatemala, Yoro, Linda Vista, Parque Nacional Pico Pijol, 09.viii.1999, J. Torres \& R. Cordero leg., 015.636EAPZ; 1 spec. (EAPZ): Guatemala, Yoro, Parque Nacional Pico Bonito, Montaña de Santa Bárbara, 01.ix.2000, A. Hernández leg., 47.289EAPZ; 1 spec. (EAPZ): Guatemala, Yoro, Parque Nacional Pico Bonito, Montaña de Santa Barbara, 20.vii.2001, A. Hernández leg., 70.133EAPZ; 1 spec. (EAPZ): Guatemala, Yoro, Parque Nacional Pico Bonito, Montaña de Santa Barbara, 26.vii.2001, A. Hernández leg., 70.166EAPZ; 1 spec. (EAPZ): Guatemala, Yoro, Parque Nacional Pico Bonito, Montaña de Santa Barbara, 06.ix.2001, A. Hernández leg., 70.137EAPZ; 1 spec. (EAPZ): Guatemala, Yoro, Parque Nacional Pico Bonito, San Rafael, 4.viii.2000, C. Meléndez leg., 39.360EAPZ. MEXICO: ChIAPAS: $1 \precsim$ (NMPC): Mexico, Tapachula; 1 (MNCN): Mexico, Chiapas, Teopisca. SAn Luis Potosi: 1 (UNSM): Mexico, San Luis Potosi, 4 mi. E of Ciudad de Maiz, vii.1981, B.
C. Ratcliffe leg.; 1 (BCRC): Mexico, San Luis Potosi, 4 mi. E of Ciudad de Maiz, vii.1981, B. C. Ratcliffe leg. Tamaulipas: 1 (LGPC): Ciudad Victoria downtown, Tamaulipas State, México, 15.x.2008, I. Martínez leg. VeraCruZ: $1 \delta$ (MSPC): Mexico, Veracruz, Los Tuxtlas, fruit trap, vi.2003; 2 I (MSPC): Mexico, Veracruz, Los Tuxtlas, viii.2012, Oscar Galindo leg.; 1 (ARPC): Mexico, Veracruz, 700 m, ix.1979, Kastenhuber leg.; 1 q (ARPC): Mexico, Veracruz, 700 m, viii.1980, Kastenhuber leg.; 2 đठ (SLCC): Volcan San Martin, 15.vii.1999, 1000 m; 1 2 우 (SLCC): Veracruz, San Martin, 15.iii.1991, J. Garcia leg.; 1 \& 1 (RBINS): Mexico, Veracruz, Catemaco, 400m, 22.viii.1992; 1 (RBINS): Mexico, Veracruz, Sotepan, 300m, x.1985. PANAMA: Chiriquí: 1 (NMPC): Panama, Chiriquí; $2 \delta$ (UNSM): Panama, Chiriqui, Santa Clara, vii.1976; $2 \delta \partial$ (UNSM): Panama, Chiriqui, Santa Clara, v.1982, B. C. Ratcliffe leg.; 1 1 (UNSM): Panama, Chiriqui, Santa Clara, vii.1976, D. Engleman leg.; 1 (UNSM): Panama, Chiriqui, Santa Clara, vi.1977, D. Engleman leg.; 1 (UNSM): Panama, Chiriqui, Santa Clara, vii.1976; 2 (BCRC): Panama, Chiriqui, Santa Clara, vii.1976; 2 dै (BCRC): Panama, Chiriqui, Santa Clara, v.1982, B. C. Ratcliffe leg.; 1 (ZMUH): Panama, Chiriqui, 1911.

Remarks. Many authors listed the publication date as Westwood, 1845 which is incorrect. According to Bousquet (2016) the pages 97 to 112 in Arcana Entomologica Vol. II. were published on 1 May 1844.

\section{Inca irroratus Chevrolat, 1833}

Ynca irrorata Chevrolat, 1833: unpaginated [original combination] Inca irroratus: BuRMEISTER \& SCHAUM (1840): 380 [mandatory change of gender agreement of species epithet]

Types. The single type was not found in the BMNH and might be deposited in the MNHN.

Locality records from literature. BRAZIL: RIO DE JANEIRO (CHEVROLAT 1833).

Remarks. See Remarks for I. burmeisteri.

\section{Inca pulverulentus (Olivier, 1789)}

Cetonia pulverulenta Olivier 1789: 57 [original combination] Trichius pulverulentus: SCHÖNHERR (1817): 100 [new combination] Inca barbicornis (partim): LePeLETIER \& SeRvilLe (1828): 381, [I. pulverulenta synonymized with $I$. barbicornis ignoring priority]

Inca pulverulentus: BuRMEISTER \& SCHAUM (1840): 379 [mandatory change of gender of species epithet, new combination and resurrection from synonymy]

Goliath barbicorne Latreille, 1816. Junior subjective synonym.

Goliath barbicorne Latreille, 1816: 187 [original combination]. Synonymized with $I$. pulverulentus and incorrectly treated as senior synonym by LePeletier \& Serville (1828: 381); priority corrected by Burmeister \& SCHAum (1840: 379).

Inca barbicornis: LePeletier \& SeRVILle (1828): 381 [new combination and mandatory change of gender of species epithet]

Types. The types of both Cetonia pulverulenta and Goliath barbicorne might be deposited in the MNHN.

Locality records from literature. BRAZIL: Rio DE JANEIRo (OHAUS 1900). ARGENTINA: Jujuy (Di Iorio 2013), Misiones (Bruch 1911, Di Iorio 2013, Richter 1913). PARAGUAY: ItAPÚA (Di Iorio 2013). Additional material examined. ARGENTINA: Misiones: $1 \propto 10$ (AKPC): Argentina, Misiones, i.2005; 1 (LGPC): Argentina, Misiones,

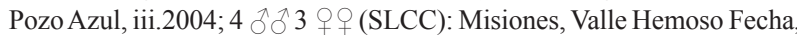
23.i.2003; 2 (RBINS): Argentina, Misiones, El Dorado, 12.iii.1993; 1 of (RBINS): Argentina, Misiones, El Dorado, 29.xi.1992, H. Schulz. BRAZIL: BAHIA: $1 \hat{\jmath}$ (MNCN): Brazil, Bahia, 9.ix.-1.x.1862, F. Amor, Expedicion al Pacifico (1862-1865). Espírito SAnto: $1 \precsim$ (ZMUH): Brazil, Santa Leopoldina, Espirito Santo, H. Rolle Berlin W; 1 (MZSP): Brasil, Espirito Santo, Itabapoana, 16. iii. 1905, J. F. Zikán leg.; 1 ( MNCN): Brazil, Espirito Santo, Santa Leopoldina, H. Rolle. Minas Gerais: $1 \subsetneq$ (ZMUH): Brazil, Minas Geraes, 1914; $1 \oint$ (MZSP): Minas, Manhumirim, i.1936; 111 (MZSP): Minas, Manhumirim, 4. 
xii.1936; 1 (MZSP): Brazil, Minas Gerais, Mar de Espanha, 19.ii.1921, J. F. Zikán leg. Paraná: $1 \precsim$ (BCRC): Brazil, Parana, Caviuna, I; $1 \precsim 1$ đ (BCRC): Brazil, Parana, Caviuna, II; 1 (MZSP): Paraná, Ourinho. Rıo DE JANEIRO: $1 \hat{\jmath}$ (NMPC): Rio de Janeiro; $1 \hat{(Z M U H): ~ B r a z i l, ~ M e n d e s, ~}$ á 92 kil de Rio de Janeiro, coll. Le Moult; 19 (ZMUH): Brazil, Theresopolis; 1 (NHRS): Rio de Janeiro, Petropolis, 5.iii.1905, F. Ohaus; 1
(NHRS): Rio de Janeiro, Corcovado, 9.i.1905, F. Ohaus; 19 (MZSP): Brasil, Rio de Janeiro, Km 65 via Dutra, 9.iv.1965, Y. Oniki leg.; 1 ठ (MNCN): Brazil, Petropolis, H. Rolle. Santa Catarina: 1 (USNM): Brazil, Santa Catarina, i.1979; 1 (SLCC): Brazil, Corupa L.C., i.1966; 1 (MZSP): Brasil, Santa Catarina, Corupá, ii.1956, A. Maller leg.; 1 + (MZSP): Brasil, Santa Catarina, Joinville, ii.1927, A. Maller leg.; 19

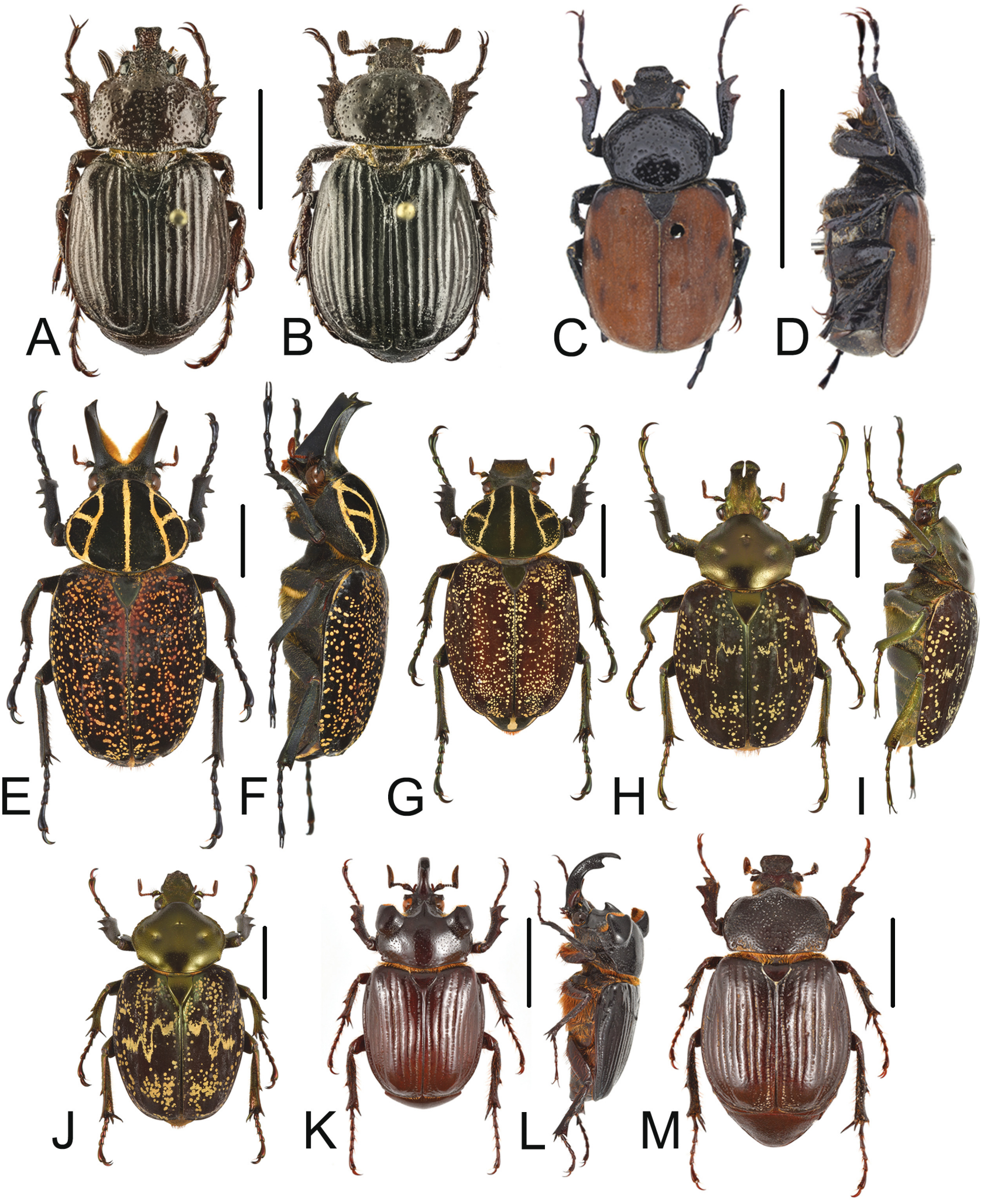

Fig 5. Habitus views of Incini species. A-C, E, G-H, J-K, M - dorsal habitus. D, F, I, L - lateral habitus. A-B - Archedinus relictus Morón \& Krikken,

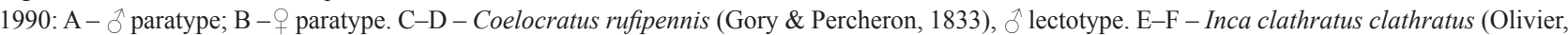
1792), G - I. clathratus sommeri Westwood, 1844, ․ H-J - Golinca bifrons (Olivier, 1789): H-I - N J - 9 . K-M - Pantodinus klugi Burmeister, 1847: $\mathrm{K}-\mathrm{L}-\mathrm{J}, \mathrm{M}-\mathrm{q}$. All scale bars $=10 \mathrm{~mm}$. Images $5 \mathrm{~A}-\mathrm{B}$ courtesy of D. Kovac, C-D by courtesy of G. Cuccodoro, 5E-M: by courtesy of R. Limoges. 
(MZSP): Brasil, Santa Catarina, Joinville, iv.1955, Dirings leg.; 1 ภ 2 + (MZSP): Brasil, Santa Catarina, Rio Natal, ii.1955, A. Maller leg., Coleção Campos Seabra; 2 d 1 (MZSP): Brasil, Santa Catarina, Rio Vermelho, i.1958, Dirings leg.; 2 9 (MZSP): Brasil, Santa Catarina, Rio Vermelho, i.1952, Dirings leg.; 111 (MZSP): Brasil, Santa Catarina, Rio Vermelho, iii.1960, Dirings leg.; 19 (MZSP): Brasil, Santa Catarina, São Bento, iii.1948; 1 (MZSP): Brasil, Santa Catarina, Timbó, iv.1935, B. Pohl leg.; 1 (RBINS): Brazil, Santa Catharina, Corupa, iv.1984, J. P. Marechal leg.; 1 of 2 (RBINS): Brazil, Santa Catharina, Corupa, ii.1984. São Paulo: 2 9 (NMPC): São Paulo, Mráz leg.; 1 (MZSP): Brasil, São Paulo, Serra do Mar, ii.1935, coll. H. Zellibor; 1 `(MZSP): Brasil, São Paulo, Pilar do Sul, 3.iii.1951, Meredo leg.; 1 (MZSP): Brasil, São Paulo, Salesópolis, Estação Biológica da Boracéia, iv.1997, Exc. DZ - IBUSP leg.; 1 (MZSP): Brasil, São Paulo, Salesópolis, Estação Biológica da Boracéia, 12.ii.1963, L. Silva \& H. Reichardt leg. PARAGUAY: $1 \uparrow$ (NMPC): Paraguay, Jesús y Tr. Šedý leg. ItaPúa: 3 đठ 1 † (ARPC): Paraguay, Encarnacion, xii.1975.

Remarks. DEJEAN (1821) and LAPORTE (1840) erroneously attributed the authorship of Inca barbicornis to MacLeay. All authors after Latreille cite the year for Inca barbicornis as 1817, but following BusQueT (2016), Latreille's description was already published in 1816. LePeletier \& ServiLle (1828) synonymized I. barbicornis (Latreille, 1816) with I. pulverulentus (Olivier, 1789), keeping I. barbicornis as valid name. Burmeister \& SCHAUM (1840) rightfully reversed the usage with $I$. pulverulentus as valid name.

\section{Genus Pantodinus Burmeister, 1847}

Pantodinus Burmeister 1847: 291 [original description]

Jeannelosis Bourgin, 1945. Junior subjective synonym. Synonymized by Howden (1972: 653)

Type species. Pantodinus: Pantodinus klugii Burmeister, 1847 (=Pantodinus klugi Burmeister, 1847) [by monotypy]. Jeannelosis: Jeannelosis auriculatus Bourgin, 1945 [by monotypy].

Gender. Masculine.

Species included. 1 species.

Distribution. Known from South Mexico to Guatemala (Fig. 6).

\section{Pantodinus klugi Burmeister, 1847 (Figs 5K-M)}

Pantodinus klugii Burmeister, 1847: 292 [original combination]

Pantodinus klugi: CANDEZE (1873): XLI [incorrect subsequent spelling, here conserved according to Art. 33.3.1 of ICZN (1999)]

Jeannelosis auriculatus Bourgin, 1945. Junior subjective synonym.

Jeannelosis auriculatus Bourgin, 1945: 120 [original combination]. Synonymized by Howden (1972: 653).

Types. Pantodinus klugi. Howden (1972) stated that the Pantodinus klugi type location is unknown to him. Burmeister described the species based on specimen(s) from the Melly collection, which is housed in MNHG. The MNHG houses one male specimen labelled "Coll. Melly. sans patrie" and "592/3 coll. Melly". If this this specimen is a syntype remains unclear. Jeannelosis auriculatus: One male holotype in MNHN (BouRgIN 1945). Locality records from literature. GUATEMALA: CHIMALTENANGo (Morón \& VaZ-de-Mello 2007), Guatemala (Howden 1972), Quetzaltenango (Morón \& Vaz-de-Mello 2007), SaCatepéquez (Howden 2010), San Marcos (Morón \& VaZ-de-Mello 2007), Sololá (Howden 1972, Morón \& Vaz-de-Mello 2007). MEXICO: Chiapas (Morón et al. 1997, Morón \& VAZ-DE-Mello 2007).

Additional material examined. GUATEMALA: $1 \uparrow 1 \uparrow$ (RBINS): Guatemala, 15.iii.1873. Chimaltenango: $3 \hat{\jmath}$ (DBPC): Guatemala, Zaragoza, vii.1994; 1 (UNSM): Guatemala, Chimaltenango, San Jose Chirijuya, viii.1975; $2 \hat{\partial}(\mathrm{BMNH})$ : Guatelama. Rodiguez, Slope of the Volcan de
Acatenango, near Patricia, $7000 \mathrm{ft}$., Godman-Salvin Coll. Guatemala: 5 ¿ð 1 (SLCC): Guatemala, El Aguacate, Mpio, Mixco, 1900m, iv.1978. Quetzaltenango: $1 \precsim 1$ (UNSM): Guatemala, Quetzaltenango, Cantel, iv.1985; 4 ठठ 1 q (UNSM): Guatemala, Quetzaltenango, Las Fuentes Georginas, Cerro Zunil, vi.2011, B. C. Ratcliffe leg.; $5 \lesssim 2$ 우 (BCRC): Guatemala, Quetzaltenango, Las Fuentes Georginas, Cerro Zunil, vi.2011, B. C. Ratcliffe leg. QuichÉ: 1 (USNM): Guatemala, El Quiche, Chichicastenango (7.3 km S), v.1973. SACATEPÉQuez: 1 (PSPC): Guatemala: Sacatepéquez, Cerro Alux, 2260 m, 24.vi.1993, B. D.Gill leg; 1 đ(PSPC): Guatemala, Sacatepéquez, Cerro Alux, 2260m, 9.vi,1991, B. D. Gill leg.; 4 (ARPC): Guatemala, Sacatepéquez, Sn. Lucas, Cerro Alux, 2200 m, 26.vi.1996; 1 o (BCRC): Guatemala, Sacatepequez, Cerro Carmona, Antigua Guatemala, vii.2009, B. C. Ratcliffe leg.; 1 spec. (EAPZ): Guatemala, Sacatepéquez, Cerro Alux, 12.vi.1991, H. \& A. Howden leg., 013.825EAPZ; 1 $\lambda 1$ (SLCC): Guatemala, San Lucas, Cerro Alux, Sacatepequez, 2200m, 25.vi.1997, Pierre Bélanger leg. SAN MARCos: 1 q (ARPC): Guatemala, San Marcos, v.2009; 4 1 q (UNSM): Guatemala, San Marcos above La Fraternidad, vi.1997, J. Monzon leg. Sololá: 2 đo 2 $\bigcirc$ (SLCC): Guatemala, Solola, Xajaac, 2325 m, 15.v.1988. MEXICO: ChiApas: 1 (CEMT): Mexico, Chiapas, Mpio: Angel A. Corzo, Reserva "El Triunfo", 13.v.2005, G. Gomez leg.

Remarks. CANDEZE (1873), while transferring Pantodinus klugii Burmeister, 1847 from "Dynastides" to "Trichides", misspelled the species epithet as "klugi" lacking one " $i$ ". This is an incorrect subsequent spelling, which has since been used by some authors (CANDEZE 1873; BATES 1889; KolBE 1909; SCHENKLING 1922; BLACKWELDER 1944; HowdEN 1968, 1972, 2010; MoRÓn \& KRIKKEN 1990; Morón et al. 1997; Morón \& VAZ-DE-Mello 2017). At the same time P. klugii was used only once by Westwood (1878). We follow Art. 33.3.1 (ICZN 1999), which states that "when an incorrect subsequent spelling is in prevailing usage and it is attributed to the publication of the original spelling, the subsequent spelling and attribution are to be preserved and the spelling is deemed to be a correct original spelling". Since Pantodinus klugi Burmeister, 1847 is in prevailing usage it is deemed to be a correct original spelling. KRAJCIK $(1999,2012)$ omitted Jeannelosis auriculatus.

\section{List of valid Incini taxa}

\section{Incini Burmeister, 1842}

\section{Archedinus Morón \& Krikken, 1990} Archedinus antoshkai Seidel \& Arriaga-Varela, 2018 Archedinus howdeni Morón \& Vaz-de-Mello, 2007 Archedinus relictus Morón \& Krikken, 1990

\section{Coelocratus Burmeister, 1842} Coelocratus rufipennis (Gory \& Percheron, 1833)

\section{Golinca Thomson, 1878}

Golinca bifrons (Olivier, 1789)

Golinca davisii (Waterhouse, 1877)

Golinca ishiharai Nagai, 1994

Golinca trevisani Valois \& Silva, 2015

Inca LePeletier \& Serville, 1828

Inca besckii Burmeister \& Schaum, 1840

Inca bonplandi (Gyllenhal, 1817)

Inca burmeisteri Burmeister, 1847

Inca clathratus clathratus (Olivier, 1792)

Inca clathratus quesneli Boos \& Ratcliffe, 1985

Inca clathratus sommeri Westwood, 1844 
Inca irroratus Chevrolat, 1833

Inca pulverulentus (Olivier, 1789)

Pantodinus Burmeister, 1847

Pantodinus klugi Burmeister, 1847

\section{Discussion}

Despite the relatively small number of taxa included in the tribe Incini, significant nomenclatural disarray was found. Our catalogue gives a framework for future research on the tribe since we uncovered and cleared all known nomenclatural problems. However, there are still some open taxonomic, faunistic, and ecological questions that need further investigation.

Archedinus now contains a third, much smaller species, Archedinus antoshkai, that is morphologically closer to $A$. howdeni than to $A$. relictus, specifically in regards to their very similar genital morphology. The distribution range of Archedinus is extended to Honduras, Cerro las Minas, $400 \mathrm{~km}$ further to the east from the previous records. So far, Archedinus has been recorded at three mountain localities spanning a range of approximately $520 \mathrm{~km}$ with no records in Guatemala. At the known localities, only one species has been recorded, indicating species' distributions may not overlap. We expect that within this wide range, additional Archedinus records and new species could be discovered. The altitudinal range of members of this genus is also increased since the holotype of $A$. antoshkai was found in a cloud forest at about $750 \mathrm{~m}$ higher than previous records. The immature stages of $A$. relictus were treated by Morón (1995). However, adult females and all immature stages of Archedinus howdeni and Archedinus antoshkai remain unknown. Since all published records are based on accidental findings, knowledge of the natural history of all species is very limited.

Specimens of the monotypic genus Coelocratus are very scarce in collections. Only two additional specimens were found by us with Cayenne as the locality. Since, French Guiana has been intensively sampled by collectors and no further specimens have been found, we doubt this taxon is found within this region. Additional collecting effort is necessary to establish its distribution and to record its ecological data.

The genus Golinca is in a problematic taxonomic state. The latest publications (Nagai 1994, Valois \& Silva 2015) described two species without reviewing any type material. Hence, it is impossible to judge the validity of the youngest two species in the genus. Here we provide many new records extending the known distribution range of the genus significantly. Ecology and immature stages of the genus remain unknown.

The genus Inca is also in need of revision. Types for Cetonia clathrata Olivier, 1792, Inca irroratus Chevrolat, 1833, Cetonia ynca Weber, 1801, Inca serricollis LePeletier \& Serville, 1828, Goliathus tricuspis Drapiez, 1820, Goliath barbicorne Latreille, 1816 and Cetonia pulverulenta Olivier, 1789 were not seen or located by us and have not been published by other authors. Here we significantly enlarged the knowledge of the distribution of the genus, but

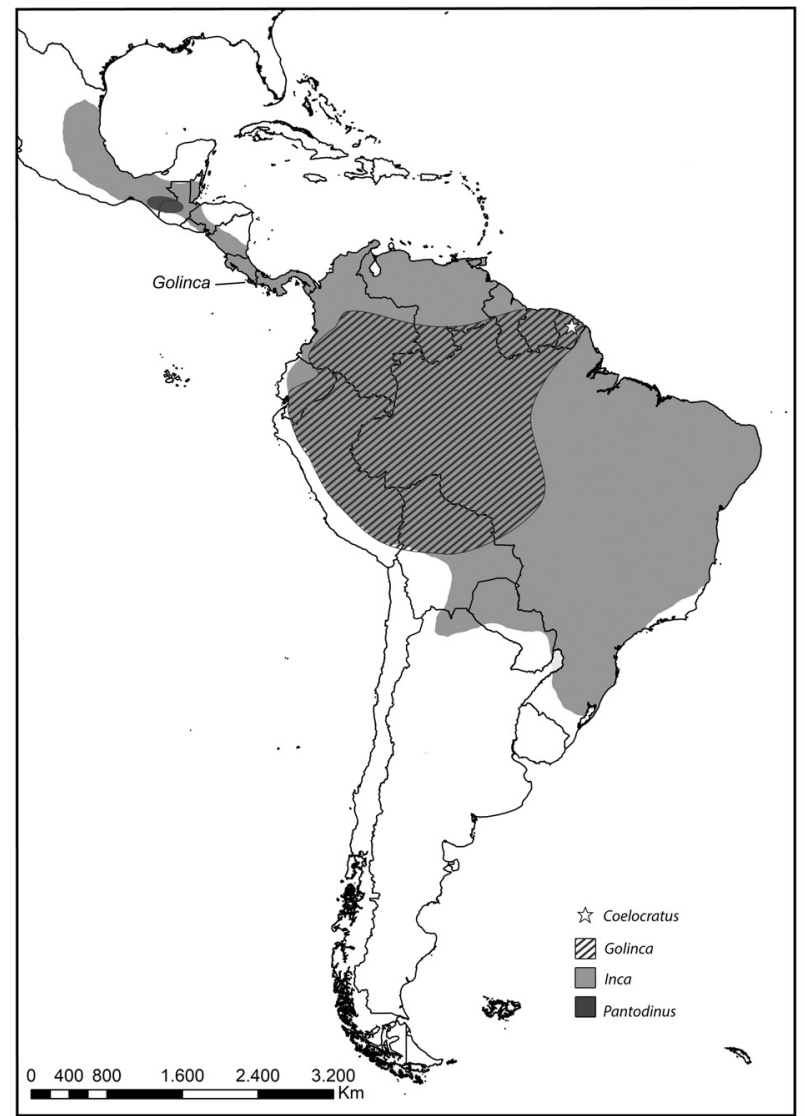

Fig 6. Generalized distribution map of Coelocratus Burmeister, 1842 (star), Golinca Thomson, 1878 (stripes), Inca LePeletier \& Serville, 1828 (gray) and Pantodinus Burmeister, 1847 (black) in Central and South America.

still data for species like Inca burmeisteri and I. irroratus remain scarce. The ecology and morphology of immature stages of I. clathratus sommeri, I. bonplandi and I. pulverulentus have been described (Costa et al. 1988; Móron 1983, 1995; Sousa et al. 2018).

The distribution of the monotypic genus Pantodinus is well established, and both sexes are known and commonly collected. Nevertheless, the ecology and immature stages remain unknown.

\section{Acknowledgments}

We thank Anton Kozlov (Moscow, Russia) who kindly provided and donated the material for description. We are indebted to François Génier (CMNC), Damir Kovac (SMF), Giulio Cuccodoro (MNHG), Stephane LeTirant (SLCC), René Limoges (Insectarium de Montréal), Dominik Vondráček (NMPC), Joachim Händel (MLUH), and Andrés Ramírez-Ponce (Conacyt-Laboratorio Regional de Biodiversidad y Cultivo de Tejidos Vegetales, Tlaxcala, Mexico) for taking pictures of specimens. We thank Andrew Smith (CMNC) for improving the manuscript. We thank Kyohei Watanabe for helping us to locate the Golinca ishiharai types. We thank all the people listed in the Material and methods for providing us with data from their collections. We thank Jean Rouch (Düsseldorf, Germany) for making his Incini material available for research in RBINS. Special thanks goes to Karla Schnei- 
der (MLUH), Joachim Händel (MLUH), Johannes Bergsten (NHRS), Martin Husemann (ZMUH), and Hans Mejlon (UUZM) for hosting the first author in their collections. Max Barclay (BMNH) is thanked for loaning the Incini types under his care. We thank Viktor Sinyaev (Moscow, Russia) for providing the habitat photos and Aleš Bezděk (Biology Centre of the Czech Academy of Sciences CAS, Institute of Entomology, České Budějovice, Czech Republic), Brett Ratcliffe (UNSM), and Lukáš Sekerka (NMPC) for helping us with literature. Miguel Ángel Morón Ríos (1954-2017) is thanked for initially commenting on the new Archedinus. His contributions to entomology will be dearly missed. MS studied the ZMHB collection with financial support of the SYNTHESYS project DE-TAF-6712.The work by MS and EAV was supported by the grant SVV $260434 / 2018$ to the Department of Zoology, Charles University, Prague, Czech Republic. RS was financially supported by the Coordenação de Aperfeiçoamento de Pessoal de Nível Superior (CAPES).

\section{References}

BATES H. W. 1889: [Trichiidae]. Pp. 377-384. In: GODMAN F. D. \& SALVIN O. (eds.): Biologia Centrali-Americana. Insecta. Coleoptera. Vol. II. Part 2. Pectinicornia and Lamellicornia. Taylor and Francis, London, xii +432 pp. +24 pls.

BERGÉ A. 1884: Enumération des Cétonides décrits depuis la publication du Catalogue de MM Gemminger \& Harold. Annales de la Société Entomologique de Belgique 28: 113-163.

BLACKWELDER R. E. 1944: Checklist of coleopterous insects of Mexico, Central America, the West Indies and South America. Part 2. Bulletin of the United States National Museum 185: 197-265.

BOOS J. \& RATCLIFFE B. C. 1985: A new subspecies of Inca clathrata from Trinidad, West Indies, and range extensions for Inca clathrata. Coleopterists Bulletin 39: 381-389.

BOUCHARD P., BOUSQUET Y., DAVIES A. E., ALONSO-ZARAZAGA M. A., LAWRENCE J. F., LYAL C. H. C., NEWTON A. F., REID C. A. M., SCHMITT M., ŚLIPIŃSKI S. A. \& SMITH A. B. T. 2011: Family-group names in Coleoptera (Insecta). ZooKeys 88: 1-972.

BOURGIN P. 1945: Revision des genres Coelosis Hope et voisins. Revue Française d'Entomologie 11(3): 118-146.

BOUSQUET Y. 2012: Catalogue of Geadephaga (Coleoptera, Adephaga) of America, north of Mexico. ZooKeys 245: 1-1722.

BOUSQUET Y. 2016: Litteratura Coleopterologica (1758-1900): a guide to selected books related to the taxonomy of Coleoptera with publication dates and notes. ZooKeys 583: 1-776.

BRUCH C. 1911: Catálogo sistemático de los coleópteros de la República Argentina. Pars IV. Familias Lucanidae, Scarabaeidae (CopriniCetoniini), Passalidae. Revista del Museo de La Plata 17: 181-223.

BURMEISTER H. 1842: Handbuch der Entomologie, volume 3. T. C. F. Enslin, Berlin, 829 pp.

BURMEISTER H. 1844: Handbuch der Entomologie, volume 4, part 1. T. C. F. Enslin, Berlin, 588 pp.

BURMEISTER H. 1847: Handbuch der Entomologie, volume 5. Coleoptera Lamellicornia Xylophila et Pectinicornia. T. C. F. Enslin, Berlin, 584 pp.

BURMEISTER H. \& SCHAUM H. 1840: Kritische Revision der Lamellicornia melitophila. Erstes Stück (Trichiadae). Zeitschrift für die Entomologie 2: 353-420.

BURMEISTER H. \& SCHAUM H. 1841: Kritische Revision der Lamellicornia melitophila. Zweites Stück. Zeitschrift für die Entomologie 3: 226-282.

CAMPOS R. 1921: Estudios sobre la fauna entomológica del Ecuador. $3^{\circ}$ Coleópteros. Revista del Colegio Nacional "Vicente Rocafuerte" 6: $24-100$.

CANDEZE E. C. A. 1873: Comptes-rendus des seance de la Societe Entomologique de Belgique. Annales de la Société Entomologique de Belgique 16: $\mathrm{xl}-\mathrm{xli}$
CHEVROLAT A. 1833: Description d'espèces nouvelles. Revue Entomologique. - Coléoptères, 10: 2 pp.

COSTA C., VANIN S. A. \& CASARI S. A. 1988: Larvas de Coleoptera do Brasil. Museu de Zoologia da Universidade de São Paulo, São Paulo, Brazil, 282 pp +165 plates.

DEJEAN P. F. M. A. 1821: Catalogue de la Collection de Coléoptères de M. le Baron Dejean. Crevot Libraire, Paris, 136 pp.

DE SOUZA SILVA A., OLIVETTE SILVA J. V., PUKER A., DE ALBUQUERQUE CORREA C. M. \& KORASAKI V. 2017: Estratificação vertical da comunidade de besouros Cetoniidae em floresta Amazônica. XIII Congresso de Ecologia do Brasil \& III International Symposium of Ecology and Evolution, At Viçosa-MG [conference abstract at published online at http://anais.ecologia2017.com.br/ listaresumos.htm].

DI IORIO O. 2013: A review of the Cetoniinae (Coleoptera: Scarabaeidae) from Argentina and adjacent countries: systematics and geographic distributions. Zootaxa 3668: 1-87.

DRAPIEZ P. A. J. 1820: Description de cinq insectes nouveaux. Annales Générales des Sciences Physiques 3: 269-274.

ERICHSON W. F. 1845: Bericht über die wissenschaftlichen Leistungen in der Naturgeschichte der Insekten, Arachniden, Crustaceen, und Entomostraceen während des Jahres 1844. Archiv für Naturgeschichte 11(2): $67-181$.

EVANGELISTA NETO J., OLIVEIRA C. M., VAZ-DE-MELLO F. Z. \& FRIZZAS M. R. 2017: Diversity of Cetoniidae (Insecta: Coleoptera) in the Cerrado of Central Brazil. Entomological Science 21(1): 84-92.

FABRICIUS J. C. 1801: Systema Eleutheratorum Secundum Ordines, Genera, Species: Adiectis Synonymis, Locis, Observationibus, Descriptionibus, volume 2. Impensis Bibliopolii Academici Novi, Kiel, 687 pp.

GORY H. \& PERCHERON A. 1833: Monographie des Cétoines et genres voisins, formant, dans les familles naturelles de Latreille, la division des Scarabées mélitophiles. J.-B. Baillière, Paris, 410 pp +77 pls.

GYLLENHAL L. 1817: [Addenda]. Pp. 196-198. In: SCHÖNHERR C. J.: Appendix ad C.J. Schönherr Synonymiam insectorum tom. 1, part. 3, sistens descriptiones novarum specierum. Scaris. Officina Lewerenziana, 266 pp. +2 pls.

HAYWARD K. J. 1935-1936: Six months collecting along the Alto Paraná, Argentina. Proceedings of the South London Entomological and Natural History Society 1935-1936: 55-83.

HOWDEN H. F. 1968: A review of the Trichiinae of North and Central America (Coleoptera: Scarabaeidae). Memoirs of the Entomological Society of Canada 100(S54): 5-77.

HOWDEN H. F. 1972: New species of Dialithus Parry and a new synonym of Pantodinus Burmeister (Coleoptera: Scarabaeidae: Trichiinae). Canadian Entomologist 104(5): 647-654.

HOWDEN H. F. 2010: In Past Years - XXXVI - 1991 - Part 2. Scarabs 54: 10-17.

ICZN 1999: International code of zoological nomenclature. Fourth edition. The International Trust for Zoological Nomenclature, London, xxix $+306 \mathrm{pp}$.

KIRBY W. 1819: A century of insects, including several new genera described from his cabinet. Transactions of the Linnean Society of London 12: 375-453.

KOLBE H. 1909: Über die Cryptodontinen, ein verbindendes Glied zwischen den Dynastiden und den melitophilen Lamellicornien. Entomologische Rundschau 26: 81-83.

KRAJCIK M. 1999: Cetoniidae of the world: Catalogue-Part II. Privately published by author, Most, Czech Republic, 95 pp.

KRAJCIK M. 2012: Checklist of the world Scarabaeoidea. Anima.X, Supplement 5: 1-278

KRIKKEN J. 1984: A new key to the suprageneric taxa in the beetle family Cetoniidae, with annotated lists of the known genera. Zoologische Verhandelingen 210: 1-75.

LAPORTE F. L. 1840: Histoire Naturelle des Insectes Coleéoptères (volume 2 of Histoire Naturelle des Animaux Articulés). P. Dumérnil, Paris, $563 \mathrm{pp}$.

LATREILLE P. A. 1816: Le règne animal distribué d'après son organisation, pour servir de base à l'histoire naturelle des animaux et d'introduction à l'anatomie comparée, par M. le Cher. Cuvier. Avec 
figures, dessinées d'après nature. Tome III, contenant les crustacés, les arachnides et les insectes. Deterville, Paris, 653 pp.

LEPELETIER A. L. M. \& SERVILLE J. G. A. 1828: Entomologie, ou histoire naturelle des crustacés, des arachnides et des insectes. Encyclopedie Methodique, Histoire Naturelle 10: 345-833.

MACLEAY W. S. 1838: Illustrations of the Annulosa of South Africa. In: SMITH A. (ed.): Illustrations of the zoology of South Africa; consisting chiefly of figures and descriptions of the objects of natural history collected during an expedition into the interior of South Africa, in the years 1834, 1835, and 1836. Invertebratae, volume 5. Smith, Elder and Co., London, 75 pp. +4 pls.

MICÓ E., MORÓN M. A., ŠÍPEK P. \& GALANTE E. 2008: Larval morphology enhances phylogenetic reconstruction in Cetoniidae (Coleoptera: Scarabaeoidea) and allows the interpretation of the evolution of larval feeding habits. Systematic Entomology 33(1): 128-144.

MOORE M. R., JAMESON M. L., GARNER B. H., AUDIBERT C., SMITH A. B. T. \& SEIDEL M. 2017: Synopsis of the pelidnotine scarabs (Coleoptera, Scarabaeidae, Rutelinae, Rutelini) and annotated catalog of the species and subspecies. ZooKeys 666: 1-349.

MORÓN M. A. 1983: Los estados inmaduros de Inca clathrata sommeri Westwood (Coleoptera, Melolonthidae, Trichiinae); con observaciones sobre el crecimiento alométrico del imago. Folia Entomológica Mexicana 56: 31-51.

MORÓN M. A. 1994: Fauna de Coleoptera Lamellicornia en las montañas del noreste de Hidalgo, México. Acta Zoológica Mexicana (Nueva Serie) 63: 7-59.

MORÓN M. A. 1995: Larva and pupa of Archedinus relictus Morón \& Krikken (Coleoptera: Melolonthidae, Trichiinae, Incaini). Pan-Pacific Entomologist 71(4): 237-244.

MORÓN M. A \& KRIKKEN J. 1990: A new Mesoamerican genus of Trichiinae (Coleoptera: Scarabaeoidea). Folia Entomológica Mexicana 78: 71-84.

MORÓN M. A., RATCLIFFE B. R. \& DELOYA C. 1997: Atlas de los escarabajos de México Coleoptera: Lamellicornia. Vol. 1 Familia Melolonthidae. Subfamilias Rutelinae, Dynastinae, Cetoniinae, Trichiinae, Valginae y Melolonthinae. Xalapa, Mexico, 249 pp.

MORÓN M. A. \& VAZ-DE-MELLO F. 2007: A new species of Archedinus (Coleoptera: Scarabaeoidea: Trichiinae) from Oaxaca, Mexico. PanPacific Entomologist 83: 110-119.

NAGAI S. 1994: A new species of the genus Golinca J. Thomson from Peru (Coleoptera: Scarabaeidae). Transactions of the Shikoku Entomological Society 20: 243-245.

OHAUS F. 1900: Bericht über eine entomologische Reise nach Centralbrasilien. Stettiner Entomologische Zeitung 61: 164-191, 193-274.

OLIVIER G. A. 1789: Entomologie ou histoire naturelle des insectes, avec leurs caractères génériques et spécifiques, leur description, leur synonymie, et leur figure enluminée. Coléoptères. Tome premier [Lucanus, Lethrus, Scarabaeus, Trox, Melolontha, Cetonia]. Baudouin, Paris [Genera sepparately paginated].

OLIVIER G. A. 1792: [Description d'une nouvelle espèce de cétoine]. Pp. 92-94. In: LAMARCK M., BRUGUIÈRE J. G., OLIVIER G. A., HAUY M. \& PELLETIER M.: Choix de mémoires sur divers objets d'histoire naturelle. Paris, France, 1-504 pp. +24 pls.

OTAVO S. E., PARRADO-ROSSELLÓ A. \& NORIEGA J. A. 2013 Superfamilia Scarabaeoidea (Insecta: Coleoptera) como elemento bioindicador de perturbación antropogénica en un parque nacional amazónico. Revista de Biología Tropical 61(2): 735-752.

PERTY J. A. M. 1830: Fasc. 2. In: Delectus animalium articulatorum, quae in itinere per Brasiliam annis MDCCCVIIMDCCCXX jussu et auspicciis Maximiliani Josephi I. Bavariae Regis augustissimi peracto collegerunt Dr. J.B. de Spix et De C.F. Ph. Martius. Accedit dissertatio de insectorum in America meridionali habitantium vitae genere, moribus et distributione geographica. J. A. M. Perty, Monachii, 224 pp. +40 pls.

PUKER A., AD'VINCULA H. L., KORASAKI V., FERREIRA F. N. \& OROZCO J. 2014: Biodiversity of Cetoniinae beetles (Coleoptera: Scarabaeidae) in introduced and native habitats in the Brazilian Atlantic Forest. Entomological Science 17(3): 309-315.

RATCLIFFE B. C., JAMESON M. L., FIGUEROA L., CAVE R. D., PAULSEN M. J., CANO E. B., BEZA-BEZA C., JIMENEZ-FERBANS L. \& REYES-CATILLO P. 2015: Beetles (Coleoptera) of Peru: a survey of the families. Scarabaeoidea. Journal of the Kansas Entomological Society 88(2): 186-207.
REAL ACADEMIA ESPAÑOLA 2014: Diccionario de la lengua Española. S.L.U. Espasa Libros, Barcelona, 2432 pp.

RESTREPO-GIRALDO H., MORÓN M. A., VALLEJO F., PARDO-LOCARNO L. C. \& LÓPEZ-ÁVILA A. 2003: Catálogo de Coleoptera Melolonthidae (Scarabaeidae Pleurosticti) de Colombia. Folia Entomológica Mexicana 42(2): 239-263.

REYES-CASTILLO P. \& LARA-VILLALÓN M. L. 1994: New record of Inca clathrata sommeri Westwood (Coleoptera: Melolonthidae, Thrichiinae) in Tamaulipas, Mexico. Acta Zoológica Mexicana (Nueva Serie) 62: 47.

RICCHIARDI E. 2002: Notes on the genus Coelocratus Burmeister, 1842 (Coleoptera: Scarabaeidae). Cetoniimania 2(1): 3-7.

RICHTER H. 1913: Ein Ausflug nach den Wasserfallen des Iguassu (Argentinien). Deutsche Entomologische Zeitschrift 1913: 170-175.

SCHAUM H. R. 1844: Observations critiques sur la famille des lamellicornes mélitophiles. Annales de la Societé Entomologique de France, Deuxiéme Serie 3: 333-426.

SCHAUM H. R. 1849: Observations critiques sur la famille des lamellicornes mélitophiles (2e. Partie). Annales de la Societé Entomologique de France, Deuxiéme Serie 7: 241-295.

SCHENKLING S. 1922: Scarabaeidae; Trichiinae, Valginae. In: JUNK W. \& SCHENKLING S. (eds.): Coleopterorum catalogues. Vol. 75. W. Junk, Berlin, pp. 1-58.

SCHERER G. 1983: Die von J. B. v. Spix und C. F. Ph. v. Martius in Südamerika gesammelten Coleopteren (Coleoptera - Scarabaeidae, Lucanidae und Passalidae). Spixiana, Supplement 9: 295-305.

SCHÖNHERR C. J. 1817: Synonymia insectorum, oder: Versuch einer Synonymie aller bisher bekannten Insecten; nach Fabricii Systema Eleutheratorum geordnet. Mit Berichtigungen und Anmerkungen, wie auch Beschreibungen neuer Arten und illuminirten Kupfern. Erster Band. Eleutherata oder Käfer. Dritter Theil. Bruzelius, Upsalla, 506 pp.

SCHULZ W. A. 1901: Biologische, zoogeographische und synonymische Notizen aus der Käferfauna des unteren Amazonenstrons. Berliner Entomologische Zeitschrift 46: 321-338.

ŠÍPEK P., FABRIZI S., EBERLE J. \& AHRENS D. 2016: A molecular phylogeny of rose chafers (Coleoptera: Scarabaeidae: Cetoniinae) reveals a complex and concerted morphological evolution related to their flight mode. Molecular Phylogenetics and Evolution 101: 163-175.

SMITH A. B. T. 2006: A review of the family-group names for the superfamily Scarabaeoidea (Coleoptera) with corrections to nomenclature and a current classification. Coleopterists Bulletin 60(5): 144-204.

SMITH A. B., HAWKS D. C. \& HERATY J. M. 2006: An overview of the classification and evolution of the major scarab beetle clades (Coleoptera: Scarabaeoidea) based on preliminary molecular analyses. Coleopterists Bulletin 60(5): 35-46.

SOLÍS A. 2007: Métodos y técnicas de recolecta para coleópteros Scarabaeoideos. Instituto Nacional de Biodiversidad, Santo Domingo, Heredia, Costa Rica, 13 pp.

SOUKUP J. 1942: Apuntes para la zoogeografía entomológica (Entomografía peruana). Boletín del Museo de Historia Natural "Javier Prado" 6: $302-342$.

SOUSA R., FUHRMANN J., KOUKLÍK O. \& ŠÍPEK P. 2018: Immature stages of three species of Inca LePeletier \& Serville, 1828 (Coleoptera: Scarabaeidae: Cetoniinae) and morphology of phytophagous scarab beetle pupa. Zootaxa 4434(1): 65-88.

THOMSON J. 1878: Typi Cetonidarum suivis de Typi Monommidarum et de Typi Nilionidarum Musaei Thomsoniani. Émile Deyroll, Paris, $44 \mathrm{pp}$.

VALOIS M. \& SILVA F. 2015: A new species of Golinca Thomson (Coleoptera: Scarabaeidae: Cetoniinae): first record of the genus for Brazil. Zootaxa 3919(1): 192-196.

WATERHOUSE C. O. 1877: Descriptions of new or little known species of Coleoptera from various localities. Cistula Entomologica 2: 223-230.

WEBER F. 1801: Observationes entomologicae, continentes novorum quae condidit generum characteres, et nuper detectarum specierum descriptiones. Bibliopolii Academici Novi, Kiel, 116 pp.

WESTWOOD J. O. 1844: Arcana Entomologica, or Illustrations of new, rare and interesting insects. Volume 2. Bradbury and Evans, London, 192 pp.

WESTWOOD J. O. 1878: IV. Descriptions of some exotic lamellicorn beetles. Transactions of the Entomological Society of London 1878: 27-37. 
